
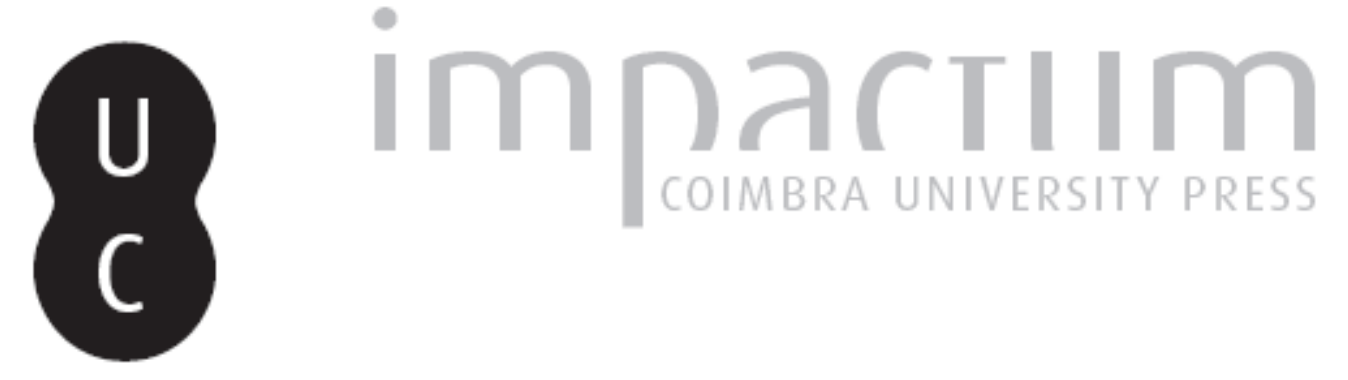

\title{
Cerâmicas áticas de Mértola
}

Autor(es): $\quad$ Arruda, Ana Margarida; Barros, Pedro; Lopes, Virgílio

Publicado por: Imprensa da Universidade de Coimbra

URL persistente:

URI:http://hdl.handle.net/10316.2/45407

DOI:

DOI:https://dx.doi.org/10.14195/1647-8657_37_5

Accessed : $\quad$ 26-Apr-2023 10:15:14

A navegação consulta e descarregamento dos títulos inseridos nas Bibliotecas Digitais UC Digitalis, UC Pombalina e UC Impactum, pressupõem a aceitação plena e sem reservas dos Termos e Condições de Uso destas Bibliotecas Digitais, disponíveis em https://digitalis.uc.pt/pt-pt/termos.

Conforme exposto nos referidos Termos e Condições de Uso, o descarregamento de títulos de acesso restrito requer uma licença válida de autorização devendo o utilizador aceder ao(s) documento(s) a partir de um endereço de IP da instituição detentora da supramencionada licença.

Ao utilizador é apenas permitido o descarregamento para uso pessoal, pelo que o emprego do(s) título(s) descarregado(s) para outro fim, designadamente comercial, carece de autorização do respetivo autor ou editor da obra.

Na medida em que todas as obras da UC Digitalis se encontram protegidas pelo Código do Direito de Autor e Direitos Conexos e demais legislação aplicável, toda a cópia, parcial ou total, deste documento, nos casos em que é legalmente admitida, deverá conter ou fazer-se acompanhar por este aviso.

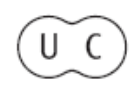


UNIVERSIDADE DE COIMBRA

FACULDADE DE LETRAS

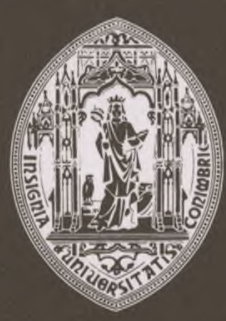

\section{CONIMBRIGA}

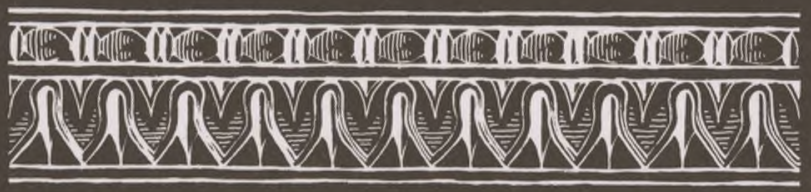

VOLUME XXXVII - 1998 
ANa MARgarida ARruda

Investigadora da UNIARQ.

PEDRo BaRros

Licenciado em Arqueologia pelo Departamento de Historia da Faculdade de Letras de Lisboa.

Colaborador da UNIARQ e do C.A.M.

VIRGÍlio LOPES

Investigador do Campo Arqueológico de Mértola (C.A.M.). Bolseiro da Fundação Gulbenkian.

CERÁMICAS ÁTICAS DE MÉRTOLA

"Conimbriga" XXXVE (1998), p. 121-149

REsumo: As escavações arqueológicas que têm vindo a decorrer em Mértola, desde 1978, permitiram recolher fragmentos de cerâmica ática datados dos séculos $\mathrm{V}$ e IV a.c. Neste trabalho, publicam-se essas cerâmicas, enquadrando-as tipológica e cronologicamente. A sua presença neste sítio do Baixo Alentejo é analisada tendo em consideração as rotas comerciais que na segunda metade do I milénio a.c. se estabeleceram no SW da Península Ibérica.

Aвsтract: Archaeological excavations, which have been taking place at Mértola, since 1978, have allowed to collect fragments of Attic pottery from the 5 th and 4th centuries BC. These potteries, are published in this paper, which discuss typology and cronology. Their presence in this place of Baixo Alentejo is analysed having into account the comercial routes, which were established in the southwest of the Iberian Peninsula in the second half of the 1st millennium $\mathrm{BC}$.

Conimbriga, 37 (1998), 121-149 
(Página deixada propositadamente em branco) 


\section{CERÂMICAS ÁTICAS DE MÉRTOLA(*)}

\section{As cerâmicas áticas de Mértola no seu contexto específico}

\subsection{Introdução}

O lote de cerâmica que aqui se apresenta é o primeiro contributo para o conhecimento da História Antiga de Mértola, ainda pouco estudada, uma vez que os dados de natureza arqueológica disponíveis são escassos. Os materiais exumados nas diversas escavações e sondagens feitas até hoje mostram-nos a existência, neste local, de um povoado durante o primeiro milénio a.c. Da ocupação pré-romana existem mesmo alguns vestígios monumentais que, no entanto, carecem de intervenções arqueológicas para a sua confirmação plena. O exemplo mais significativo é fornecido pela grande muralha que circunda os cerros à volta da vila de Mértola, formando uma meia lua com início e fim no rio Guadiana. De momento encontra-se apenas reconhecida em termos topográficos e terá, segundo se pensa, um comprimento aproximado de 1,5 Km (Torres, 1994: 366).

O burgo, é sabido, reuniu um conjunto de factores determinantes para a sua ocupação e para uma importância que foi confirmada ao longo do tempo. Por um lado, a sua localização estratégica, implantado no topo de uma elevação ladeada pelo rio Guadiana a nascente e pela ribeira de Oeiras a Poente, deu-lhe excelentes condições naturais de defesa. Por outro, o ser ponto extremo da navegabilidade do rio Guadiana, uma vez

(*) Os autores agradecem ao Dr. Cláudio Torres, director do Campo Arqueológico de Mértola, e responsável pelas escavações arqueológicas, a cedência dos materiais para estudo.

Conimbriga, 37 (1998), 121-149 
que, para montante, o rio possui uma garganta rochosa com um desnível com cerca de 14 metros que impossibilita a passagem a qualquer barco. Estes factos tomaram Mértola um importante entreposto mercantil, com um vasto territorio interno, em permanente contacto com o não menos vasto Mar Mediterrâneo. Pelo porto da cidade escoavam-se, por exemplo, o ouro, a prata e o cobre extraídos das entranhas da faixa piritosa (Oliveira, 1996: 11). E, claro está, a ele arribavam as gentes de mil paragens e os mais diversos produtos e artefactos.

Resta referir que um primeiro conjunto de materiais da Idade do Ferro foi objecto de publicação recente (Rego et al, 1996), tendo então sido apresentados alguns desenhos de cerâmica grega.

\subsection{Contextualização dos achados}

Os fragmentos de cerâmica ática exumados em Mértola, em termos de localização, são oriundos de locais próximos e podem ser englobados numa área comum: a vertente norte do Castelo. Os materiais são assim apresentados tomando por referência esses mesmos locais, a saber: a encosta do castelo; Alcáçova; a chamada «Casa do Pardal» e o quintal de A. J. Pereira. Duma segunda área, o Rossio do Carmo, situada fora do recinto amuralhado e nas cercanias da antiga via de ligação a Beja, provém um único fragmento, caso isolado que aqui se refere para uma melhor percepção dos horizontes culturais e ocupacionais do período histórico em causa.

A encosta do Castelo é uma área arqueológica que se estende entre a muralha norte do castelo e a entrada do actual cemitério, que se encontra apenas parcialmente escavada e em que se atingiram, fundamentalmente, os níveis islâmicos.

$\mathrm{Na}$ zona da Alcáçova, as escavações arqueológicas, em curso desde 1978, têm-se centrado em quatro níveis de ocupação. Um primeiro, com a designação estratigráfica de la, corresponde aos estratos de revolvimento superficial recentes. No nível lb implantou-se uma necrópole cristã (séculos XIII-XVII). Neste nível, extremamente remexido, foram encontrados alguns fragmentos de cerâmica ática. Um terceiro, cuja referência estratigráfica é le, e sob este um quarto nível designado por nível 2a, correspondem respectivamente, a um bairro do período islâmico (séculos XI-XIII) e às estruturas do forum de Myrtilis. É destes quatro estratos que provém a maior parte dos fragmentos 
estudados. Parece não haver dúvidas que o programa de obras do período romano - construção da plataforma artificial onde assenta o forum e o criptoportico -, terá contribuído para a destruição das estruturas e dos níveis ocupacionais contemporâneos das cerâmicas aqui estudadas.

$\mathrm{Na}$ zona a norte do forum situa-se o quintal de A. J. Pereira, onde foram feitas recolhas de superfície. Este local apresenta, no entanto, grandes potencialidades arqueológicas dada a diversidade de materiais aqui encontrados e que possuem, além do mais, uma cronologia bastante ampla. O mesmo facto foi constatado numa intervenção de emergência levada a cabo, em 1995, pelo Campo Arqueológico de Mértola numa área contígua da referida anteriormente, designada «Casa do Pardal». A realização de uma obra particular nesse local, situado à entrada de Mértola, nas proximidades do troço de muralha romana que forma a parede exterior do criptoportico, levou a uma intervenção de emergência.

Após a demolição da ruína e da remoção dos entulhos, procedeu-se à limpeza de algumas secções do perfil. Para o efeito foram definidas três áreas de limpeza, denominadas Corte I, II e Hl. As elevadas dimensões do perfil (cerca de 30 metros de comprimento e 9,5 metros de altura) condicionaram os trabalhos e a análise da extensão longitudinal das camadas do corte. Posteriormente fez-se a recolha de grande quantidade de materiais, constituídos essencialmente por fragmentos de cerâmica, acumulados em camadas sucessivas ao longo dos séculos, formando assim um perfil com uma estratigrafía coerente e contínua. As balizas cronológicas dessa estratigrafía estão delineadas pela cerâmica da Idade do Bronze/Ferro e as cerâmicas islâmicas, sendo muito raros os materiais posteriores a esse período. É possível que esse facto esteja relacionado com a mudança de funções da plataforma do forum/Alcáçova, o qual passou a albergar, após a Reconquista, uma necrópole cristã.

No Rossio do Carmo, os materiais encontrados provêm de uma possível necrópole da Idade do Ferro: um fragmento cerâmico - que se encontrava sob o pavimento do anexo sul da basílica paleocristã - e uma esteia contendo uma inscrição em caracteres do Sudoeste, e com uma cronologia balizada entre o século VII e V a.c. Recolhida acidentalmente em contexto não arqueológico, é possível que tenha sido reutilizada como tampa de uma sepultura paleocristã (Faria, 1994: 61-63). 


\section{As cerámicas áticas de Mértola: classificação tipológica, estilos decorativos e cronologias}

\subsection{Introdução}

Em Mértola, foram encontrados 70 fragmentos de cerámica ática. 9 são de figuras vermelhas e 61 de vemiz negro. Os fragmentos são todos de pequenas dimensões (situação frequente em contextos de habitat) o que impediu, algumas vezes, a classificação tipológica das peças e impossibilitou, na maioria dos casos, uma identificação exacta dos pintores dos vasos. No entanto, o conjunto é razoavelmente homogéneo do ponto de vista cronológico e o seu estudo permite discutir alguns aspectos do comércio da cerâmica ática no território actualmente português.

Mértola importou cerâmica grega a partir da segunda metade do século V a.c., situação que se deduz da presença de taças tipo Castulo e de um fragmento de kylix, de figuras vermelhas, cuja cronologia podemos centrar entre 430/425 a.c. As importações prolongaram-se até cerca de 350 a.c., o que significa que duraram cerca de 80 anos. Todavia, podemos considerar que o momento alto destas importações se centra entre o último quartel do século $\mathrm{V}$ a.c. e o primeiro do século IV a.c. Esta situação não destoa do que se verifica em todo o actual território português, muito particularmente na região sul (Arruda, 1994 e 1997). De facto, a grande maioria das importações de cerâmica grega para o nosso território data do início do século IV a.c., mas já se registam cerâmicas provenientes da Ática a partir do último quartel do século $\mathrm{V}$ a.c.

Também o repertório formal dos vasos de vemiz negro e os pintores representados no conjunto em análise é similar ao que já conhecíamos na região, registando-se, no entanto, algumas novidades formais (forma 21/25 e lekythos arybalistica, Fig. 7, n. $^{\circ} 1$ e Fig. 8, n. ${ }^{\circ}$ ).

A divulgação deste conjunto de materiais pareceu-nos fundamental. O seu número é razoavelmente grande (o maior até hoje encontrado no nosso território) para permitir uma análise coerente e contextualizada da sua presença neste local, e as características que possui possibilitam uma leitura mais ampla sobre as rotas comerciais e as redes do comércio existentes, durante a segunda metade do I milénio a.c., no SW da Península Ibérica. 


\subsection{A cerámica de figuras vermelhas}

Os nove fragmentos de cerâmica grega decorados corn a técnica das figuras vermelhas (todos desenhados) são todos de reduzidas dimensões, o que dificultou a identificação dos pintores. No entanto, podemos avançar que oito deles pertencem ao chamado Período Clássico Tardio II e estão globalmente incluídos naquilo que se costuma designar por estilo Kerch. Estes oito fragmentos (fundos, paredes e uma asa) pertencem a kylikes e devem datar-se da primeira metade do século IV a.c.

Alguns deles são obra do chamado grupo de Viena 116, como é o caso do exemplar da Fig. 3 n. ${ }^{\circ}$ 1. Esta peça tem bons paralelos em território peninsular, nomeadamente em Ampúrias (Trías, 1967/68, p. 148, lâmina LXXXI, n. ${ }^{\circ}$ 1) e em Baza (Presedo Velo, 1982, p. 125,126 e 284, fig. 95). Estas kylikes, do século IV a.c., estão bem documentadas no Museu de Viena, Áustria (C.V.A. Áustria, pi. 34, 1-4, Viena). Pintadas, quase seguramente pelo grupo de Viena 116 são também as kylikes das Fig. 3 , n. $^{\circ} 2$ e 3 e Fig. 4 , n. ${ }^{\circ} 1,2$ e 3.

Seria fastidioso apresentar aqui todos os paralelos para as restantes peças pertencentes ao estilo Kerch. Resta-nos pois dizer que as decorações que ostentam correspondem aos motivos mais comuns deste estilo, nomeadamente jovens com os seus mantos, palmetas ou espirais que estão presentes em quase todos os sítios da Península Ibérica onde existe cerâmica ática do século IV a.c.

$\mathrm{O}$ fragmento representado na Fig. $3, \mathrm{n}^{\circ} 4$ possui características, tanto ao nível formal como do ponto de vista decorativo, que o diferenciam do conjunto da cerâmica de figuras vermelhas de Mértola. Não se trata de uma kylix, e pertence à fase I do Período Clássico Tardio, devendo datar-se do final do terceiro quartel do século $\mathrm{V}$ a.c. A dimensão do fragmento não permitiu identificar, com segurança, a forma a que pertenceu (no entanto poderá tratar-se de um krater), e dificultou, consideravelmente, a atribuição de um pintor para este vaso. A ausência de pormenores importantes na figura humana representada, como os olhos, o nariz e as orelhas, perturbaram a classificação. Não arriscamos pois qualquer identificação precisa, não desprezando, porém, a hipótese de se tratar de uma obra do Pintor de Dinos, ou do Pintor de Chrysis (este da escola do primeiro), ou, mais precisamente, e seguindo Beazley «à maneira do Pintor de Dinos» ou «próximo do Pintor de Chrysis» (Beazley, 1984, ARV, vol II, p. 1151-9). Quanto ao personagem representado, pouco se pode dizer, uma vez que não há elementos suficientes que permitam avançar qualquer hipótese minimamente válida. 
Até há pouco tempo, não eram conhecidas obras deste Pintor na Península Ibérica, que estava, no entanto, bem representado na Grécia, Itália, Crimeia e Próximo Oriente. É precisamente do territorio portugués que provém um outro vaso que, sob reservas, um de nós já atribuiu também ao pintor de Dinos ou de Chrysis (Arruda, 1997). Trata-se do fragmento de krater do povoado de Santa Olaia, Figueira da Foz, onde o exemplar de Mértola pode ir buscar os seus melhores paralelos (ibid.).

Descrição dos fragmentos:

Mértola, 94, 4J, lb. Fig. 3, n. ${ }^{\circ} 1$

Fragmento de fundo e pé de uma kylix de figuras vermelhas, decorada no fundo interno. A decoração consta de uma banda de verniz negro, atrás da qual existe uma linha de pontos também de verniz negro. A linha pode corresponder ao limite de um manto, o que significa que estaríamos na presença de um jovem envolto na sua himation, decoração frequente no estilo Kerch. Áreas reservadas: superfície de apoio do pé, linha na parede interna do pé e dois círculos concêntricos no fundo extemo. Pé anelar e moldurado. Diâmetro do pé: $74 \mathrm{~mm}$. Espessura do fundo: $6 \mathrm{~mm}$. Pasta dura, compacta, bem depurada e de cor castanha clara, alaranjada. Verniz negro, aderente e baço.

Período Clássico Tardio II. Estilo Kerch. Pintor de Viena 116. Paralelos no C.V.A. Áustria 34, Viena, estampa 34, Baza, Ampúrias.

Cronologia: meados do século IV a.c.

Mértola, 95, Casa do Pardal. Fig. 3, n. ${ }^{\circ} 2$

Fragmento de parede de kylix de figuras vermelhas, com decoração nas superfícies interna e extema e com área de fractura na parede externa que corresponde ao arranque de uma asa. O que resta da decoração da superfície extema indica que se trata de uma palmeta ou espiral. Na superfície interna, são visíveis duas linhas reservadas que limitam a área decorada. Nesta são apenas perceptíveis zonas de verniz negro que alternam com áreas reservadas que compunham os motivos decorativos, que não são identificáveis. Espessura da parede: $4 / 5 \mathrm{~mm}$. Pasta dura, compacta, bem depurada, de cor rosa alaranjada. Verniz negro, baço, pouco aderente

Período Clássico Tardio II. Estilo Kerch.

Cronologia: primeira metade do século IV a.c.

Mértola, 95, Casa do Pardal, 4L, lb. Fig. 3, n. ${ }^{\circ} 3$

Fragmento de parede de kylix de figuras vermelhas, com decoração nas superfícies interna e externa. Na superfície extema é visível o que resta de um braço e de uma mão. No interior, a área decorada está limitada por dois círculos concêntricos em reserva, mas da decoração propriamente dita nada sobra. Espessura da parede: $3 / 4 \mathrm{~mm}$. Pasta dura, compacta, bem depurada, de cor rosada. Verniz negro, brilhante e aderente. 


\section{Período Clássico Tardio II. Estilo Kerch.}

Cronologia: primeira metade do século IV a.c.

Mértola, 95, Casa do Pardal, Corte 3. Fig. 3, n. ${ }^{\circ} 4$

Fragmento de parede de vaso áticO de figuras vermelhas. Decoração na superfície externa: parte do rosto e tronco de uma personagem masculina, de frente, com barba, e com cabeça virada para a direita. Espessura da parede: 4 $\mathrm{mm}$. Pasta dura, compacta, bem depurada de cor rosada. Verniz negro, brilhante e aderente.

Período Clássico Tardio I.

Cronologia: final do último quartel do século $\mathrm{V}$ a.c.

Mértola, 83, 1, IV, R.S. Fig. 4, n. ${ }^{\circ} 1$

Fragmento de parede de kylix de figuras vermelhas, decorada nas superfícies interna e externa. Decoração: na superfície externa, os traços de verniz negro que alternam com as áreas reservadas parecem representar o que resta de duas espirais. Na superfície interna, a decoração que existe não é perceptível de identificação. Espessura: $5 \mathrm{~mm}$. Pasta dura, compacta, bem depurada de cor rosada escura. Verniz negro, brilhante e mais ou menos aderente.

Período Clássico Tardio II. Estilo Kerch.

Cronologia: primeira metade do século IV a.c.

Mértola, 94, 3J, lb. Fig. 4, n. ${ }^{\circ} 2$

Fragmento de fundo com arranque de pé de kylix de figuras vermelhas, decorado na superfície interna. A decoração da parede interna do fundo representa um braço de uma figura humana. O fundo externo é reservado. Espessura da parede: $4 \mathrm{~mm}$. Espessura do fundo: $5 \mathrm{~mm}$. Pasta dura, compacta, bem depurada de cor rosa escura. Verniz negro, pouco aderente e com algum brilho.

Período Clássico Tardio II. Estilo Kerch.

Cronologia: primeira metade do século IV a.c.

Mértola, 95, Casa do Pardal. Fig. 4, n. ${ }^{\circ} 3$

Fragmento de fundo com arranque de pé de kylix de figuras vermelhas, decorado na superfície interna. O que resta da decoração, vestígios de uma himation, permite-nos afirmar que no fundo interno estaria representado um jovem envolvido no seu manto. A parede interna do pé está reservada. O fundo externo apresenta um círculo largo de verniz negro e outro, mais estreito, em reserva. Espessura da parede: $4 \mathrm{~mm}$. Espessura do pé: $6 \mathrm{~mm}$. Pasta dura, compacta, bem depurada de cor laranja clara. Verniz negro, pouco aderente e com algum brilho.

Período Clássico Tardio II. Estilo Kerch.

Cronologia: primeira metade do século IV a.c.

Mértola, 92, C2, IV, lc. Fig. 4, n. ${ }^{\circ} 4$

Fragmento de bordo de kylix de figuras vermelhas. Na superfície externa, uma linha curvilínea reservada é o que resta da decoração que o vaso possuía,

Conimbriga, 37 (1998), 121-149 
não nos sendo permitido adiantar mais nada quanto aos prováveis elementos figurados. Espessura da parede: $3 \mathrm{~mm}$. Pasta dura, compacta, bem depurada de cor castanha clara. Verniz negro, pouco aderente e com algum brilho.

Período Clássico Tardio II. Estilo Kerch.

Cronologia: primeira metade do século IV a.c.

Mértola, 92, 7N, lb. Fig. 4, n. ${ }^{\circ} 5$

Fragmento de asa horizontal pertencente a uma kylix de figuras vermelhas, com a superfície interna em reserva. Espessura: 9/11 mm. Pasta dura, compacta, bem depurada de cor rosa alaranjada. Verniz negro, aderente e com algum brilho.

\subsection{A cerâmica de verniz negro}

\subsubsection{As taças Castulo}

Um dos grupos da stemless cup é o das inset lip ou taças Castulo, como passaram a ser conhecidas após a generalização do uso do termo usado por Shefton em 1982, tendo-se, a partir de então, abandonado a terminologia americana (inset lip), bem como a designação tipológica tradicional (Lamboglia 42A). Esta forma está incluída na tipologia de Morei, onde é o tipo 4271 a 1.

Esta taça caracteriza-se por possuir: (1) um pé anelar espesso e largo, com uma canelura; (2) um lábio côncavo na face externa e ressalto bem marcado na face interna; (3) fundo externo decorado com um ou dois círculos concêntricos e ponto central de verniz negro. A superfície de apoio do pé é geralmente reservada, assim como a sua parede externa (apenas nos exemplares mais antigos).

Esta forma é uma criação do segundo quartel do século $V$ a.c. e perdura até à primeira metade do século IV a.c.

$\mathrm{Na}$ Península Ibérica, as taças Castulo são muito abundantes, desde a Catalunha à Andaluzia Ocidental, passando pelo Levante mediterrâneo e atingindo a Estremadura espanhola e a região de Castela, registandose igualmente em Ibiza. Em Portugal, as taças Castulo estão presentes em sítios do Sul de Portugal, nomeadamente em Castro Marim (Arruda, 1994 e 1997), Corvo I, Castro Verde (Maia, 1986 e 1987), Castro da Azougada (Moura), Femão Vaz (Ourique) e Alto do Castelinho da Serra, (Montemor-o-Novo).

A maioria das taças Castulo encontradas em Espanha surge 
associada a vasos áticos que não perduram até ao século IV a.c. e no Cerro Macareno foram encontradas em níveis do segundo quartel do século V a.c. (Pellicer Catalán, 1982: 96, fig. 52). Os contextos portugueses são mais difíceis de estabelecer, desconhecendo-se a proveniência estratigráfica da maioria destas peças.

De Mértola são provenientes 7 fragmentos de taças Cástulo, sendo 6 bordos (Fig. 5, n. ${ }^{\circ}$ 1-6) e 1 pé (Fig. 5, n. ${ }^{\circ}$ 7). Adata dos bordos deve situarle na segunda metade do século $\mathrm{V}$ a.c. $\mathrm{O}$ único pé desta forma recuperado em Mértola tem as superfícies externas reservadas, o que permite, com base nos resultados da ágora de Atenas (Sparkes e Talcott, 1970: 101-102), datá-lo de meados do século V a.c.

Descrição dos fragmentos:

Mértola, 95, Casa do Pardal. Fig. 5, n. ${ }^{\circ} 1$

Fragmento de bordo e parede de taça Castulo. Lábio côncavo na superfície extema. Um ressalto na superfície interna marca a ligação do lábio à parede. Diâmetro do bordo: $133 \mathrm{~mm}$. Espessura da parede: 3/7 mm. Pasta dura, compacta, bem depurada, sendo visíveis minúsculas partículas de mica. Cor laranja clara. Verniz negro, brilhante e acetinado, aderente, espesso.

Mértola, 95, Casa do Pardal. Fig. 5, n. ${ }^{\circ} 2$

Fragmento de bordo e parede de taça Castulo. Lábio côncavo na superfície extema. Um ressalto na superfície interna marca a ligação do lábio à parede. Diâmetro do bordo: $166 \mathrm{~mm}$.. Espessura da parede: 3/7 mm. Pasta dura, compacta, bem depurada, sendo visíveis minúsculas partículas de mica. Cor beije rosada. Verniz negro, brilhante e acetinado, muito aderente, espesso.

Mértola, 92, Quintal de A. J. Pereira. Fig. 5, n. ${ }^{\circ} 3$

Fragmento de bordo e parede de taça Castulo. Lábio côncavo na superfície extema. Um ressalto na superfície interna marca a ligação do lábio à parede. Diâmetro do bordo: $138 \mathrm{~mm}$. Espessura da parede: 4/8 mm. Pasta dura, compacta, mais ou menos depurada, sendo visíveis minúsculas partículas de mica. Cor rosa clara. Verniz negro, brilhante e acetinado, aderente, espesso.

Mértola, 82, 3A, 150. Fig. 5, n. ${ }^{\circ} 4$

Fragmento de bordo e parede de taça Castulo. Lábio côncavo na superfície extema. Um ressalto na superfície interna marca a ligação do lábio à parede. Diâmetro do bordo: $174 \mathrm{~mm}$. Espessura da parede: 5/8 mm. Pasta dura, compacta, bem depurada, sendo visíveis minúsculas partículas de mica. Cor beije clara. Verniz negro, brilhante e acetinado, aderente, espesso.

Mértola, 89, 13 H, lb. Fig. 5, n. ${ }^{\circ} 5$

Fragmento de bordo e parede de taça Castulo. Lábio côncavo na superfície extema. Um ressalto na superfície interna marca a ligação do lábio à parede. $\mathrm{Na}$

Conimbriga, 37 (1998), 121-149 
superficie externa, imediatamente a seguir ao bordo, urna zona de fractura que corresponde ao arranque da asa. Diámetro do bordo: $137 \mathrm{~mm}$. Espessura da parede: $2 / 7 \mathrm{~mm}$. Pasta dura, compacta, bem depurada, sendo visíveis minúsculas partículas de mica. Cor rosa escura. Vemiz negro, brilhante e acetinado, pouco aderente, pouco espesso.

Mértola, 95, Casa do Pardal. Fig. 5, n. ${ }^{\circ} 6$

Fragmento de bordo e parede de taça Castulo. Lábio côncavo na superfície externa. Um ressalto na superfície interna marca a ligação do lábio à parede. $\mathrm{Na}$ superfície externa, imediatamente a seguir ao bordo, uma zona de fractura que corresponde ao arranque da asa Espessura da parede: 4/7 mm. Pasta dura, compacta, bem depurada. Cor castanho amarelada clara. Vemiz negro, brilhante e acetinado, aderente, espesso.

Mértola, 92, Quintal de A. J. Pereira. Fig. 5, n. ${ }^{\circ} 7$

Fragmento de fundo e pé de taça Castulo. Pé anelar e moldurado, com duas caneluras na superfície interna. Áreas reservadas: superfície de apoio e face extema do pé. Diâmetro da base: $77 \mathrm{~mm}$. Espessura do fundo: $4 \mathrm{~mm}$. Espessura do pé: $12 \mathrm{~mm}$. Pasta dura, compacta, bem depurada, sendo visíveis minúsculas partículas de mica. Cor rosa. Vemiz negro, brilhante e acetinado, aderente, espesso.

\section{Mértola, 83, 3A, 750 A. Não ilustrado}

Fragmento de parede de taça Castulo, com ressalto na superfície interna que marcava a ligação do lábio à parede. Espessura da parede: 4/7 mm. Pasta dura, compacta, bem depurada, sendo visíveis minúsculas partículas de mica. Cor rosa clara. Vemiz esverdeado, brilhante e acetinado, aderente, espesso.

Mértola, R. C., 6N, 2. Não ilustrado

Fragmento de parede de taça Castulo, com ressalto na superfície interna que marcava a ligação do lábio à parede. Espessura da parede: 4/8 mm. Pasta dura, mas ou menos compacta, pouco depurada, sendo visíveis minúsculas partículas de mica. Cor laranja clara. Vemiz negro, brilhante e acetinado, aderente, espesso.

Mértola, 95, Casa do Pardal. Não ilustrado

Fragmento de parede de taça Castulo, com ressalto na superfície interna que marcava a ligação do lábio à parede. Espessura da parede: 5/7 mm. Pasta dura, compacta, bem depurada. Cor rosa clara. Vemiz negro, brilhante e acetinado, aderente, pouco espesso.

Mértola, 85, GB 700. Não ilustrado

Fragmento de parede de taça Castulo, com ressalto na superfície interna que marcava a ligação do lábio à parede. Espessura da parede: $4 / 7 \mathrm{~mm}$. Pasta

Conimbriga, 37 (1998), 121-149 
dura, mais ou menos compacta, depurada. Cor castanha esverdeada clara. Vemiz negro, brilhante e acetinado, muito aderente, espesso.

\subsubsection{As stemless cups}

Alguns fundos de taças, genericamente chamadas «stemless cup», encontrados em Mértola não permitem um enquadramento tipológico preciso. Os fragmentos podem fazer parte de «taças Castulo (inset lip)» ou de «plain rim cup».

No entanto, o perfil do pé, por um lado, e o facto de a face extema do pé não ser reservada, mas de vemiz negro, por outro, são características que indicam, com segurança, que se trata de materiais dos finais do século

$\mathrm{V}$ a.c. ou, mais possivelmente, do primeiro quartel do século IV a.c.

De facto, as taças Castulo, ou inset lip, apresentam, como já vimos, pés moldurados de perfil muito semelhante aos exemplares em análise. No entanto, os pés das taças tipo Castulo têm, durante o século V a.c., as suas superfícies externas reservadas, característica que se perde na transição para o século IV a.c.

As taças do tipo plain rim apresentam, durante grande parte do século $\mathrm{V}$ a.c., pés com ambas as faces convexas. Só a partir do último quartel deste século os pés destas taças passam a ser moldurados tomándose semelhantes aos das taças Castulo.

Assim, não restam dúvidas que o exemplar da Fig. 7 n. ${ }^{\circ} 4$ pertence a «plain rim cup» do século $\mathrm{V}$ a.c., uma vez que aqui ambas as faces do pé são convexas. Os n. ${ }^{\circ} 3,5$ e 6 da Fig. 7 apresentam pés moldurados, com as superfícies externas cobertas de vemiz negro. Trata-se portanto de stemless cups (taças Castulo ou, mais provavelmente, plain rim cups), do século IV a.c.

O bordo n. ${ }^{\circ} 1$ da Fig. 8 levanta menos questões de ordem formal e tipologica, já que se trata, indubitavelmente, de uma plain rim cup.

Mértola também entregou aos arqueólogos 4 asas pertencentes a kylikes, cuja tipologia não é possível determinar com rigor, como por exemplo a da Fig. 8, n. ${ }^{\circ} 2$.

Descrição dos fragmentos:

Mértola, 95, Casa do Pardal. Fig. 7, n. 3

Fragmento de fundo, pé e parede de uma kylix do tipo stemless cup (Castulo ou plain rim cup). Pé anelar, com caneluras na superfície extema e um ressalto 
na superficie interna. Áreas reservadas: superfície de apoio do pé e fundo externo. Diámetro da base: $93 \mathrm{~mm}$. Espessura do fundo: $14 \mathrm{~mm}$. Espessura do pé: 14 mm. Pasta dura, compacta, bem depurada de cor rosa clara. Vemiz negro, brilhante, acetinado, espesso e pouco aderente.

Cronologia: primeira metade do século IV a.c.

Mértola, 95, Casa do Pardal. Fig. 7, n. ${ }^{\circ} 4$

Fragmento de fundo, pé e parede de uma kylix do tipo plain rim cup. Pé anelar, com ambas as superfícies convexas. Ressalto no fundo externo e na superfície interna do pé. Áreas reservadas: superfície de apoio do pé e fundo externo. Diâmetro da base: $80 \mathrm{~mm}$. Espessura do fundo: $6 \mathrm{~mm}$.. Espessura do pé: $10 \mathrm{~mm}$. Pasta dura, compacta, bem depurada de cor rosa clara. Vemiz negro, brilhante, acetinado, espesso e muito aderente.

Cronologia: finais do século $\mathrm{V}$ a.c.

Mértola, 87, H H, 27, la. Fig. 7, n. ${ }^{\circ} 5$

Fragmento de fundo, pé e parede de uma kylix do tipo stemless cup (Castulo ou plain rim cup). Pé anelar, com a superfície interna convexa e a extema planoconvexa. Ressaltos no fundo extemo e nas superfícies interna e extema do pé. Áreas reservadas: superfície de apoio do pé e fundo extemo. Diâmetro da base: $91 \mathrm{~mm}$. Espessura do fundo: $5 \mathrm{~mm}$. Espessura do pé: $12 \mathrm{~m}$. Pasta dura, compacta, bem depurada de cor beije. Vemiz castanho, baço, pouco espesso, pouco aderente.

Cronologia: primeira metade do século IV a.c.

Mértola, 95, Casa do Pardal. Fig. 7, n. $^{\circ} 6$

Fragmento de fundo e pé de uma kylix do tipo stemless cup (Castulo ou plain rim cup). Pé anelar, com a superfície interna convexa e a extema côncava. Ressalto na superfície interna do pé na ligação ao fundo externo. Áreas reservadas: superfície de apoio do pé e fundo extemo. Diâmetro da base: 180 $\mathrm{mm}$. Espessura do fundo: $4 \mathrm{~mm}$. Pasta dura, pouco compacta, bem depurada de cor rosa clara. Vemiz negro, brilhante, acetinado, pouco espesso e pouco aderente.

Cronologia: finais do século IV a.c.

Mértola, 95, Casa do Pardal. Fig. $8, \mathrm{n}^{\circ} 1$

Fragmento de bordo de uma kylix do tipo plain rim cup. Diâmetro do bordo: $176 \mathrm{~mm}$. Espessura da parede: $3 \mathrm{~mm}$. Pasta dura, compacta, bem depurada, de cor rosa clara. Vemiz negro, aderente, espesso e baço.

Cronologia: finais do século V e inícios do IV a.c.

Mértola , 87, 7E, la. Fig. 8, n. $^{\circ} 2$

Fragmento de asa horizontal pertencente a uma kylix do tipo stemless cup. Espessura: $10 \mathrm{~mm}$. Pasta dura, compacta, bem depurada, de cor rosa clara. Vemiz negro, brilhante e pouco aderente. 
Mértola, 89, 148, la. Não ilustrado.

Fragmento de fundo e pé de urna kylix do tipo stemless cup. Pé anelar e fundo com restos de decoração em guilloché. Espessura do pé: $5 / 8 \mathrm{~mm}$. Espessura do fundo: $5 \mathrm{~mm}$. Pasta dura, compacta, bem depurada de cor rosa alaranjada. Vemiz negro, brilhante, pouco espesso e aderente.

Mértola, 92, 7M, la. Não ilustrado.

Fragmento de fundo, parede e pé de uma kylix do tipo stemless cup. Pé anelar, com duas caneluras na parede externa e uma na parede interna. Espessura do pé: 9/1 lmm. Espessura do fundo: $3 \mathrm{~mm}$. Pasta dura, compacta, muito bem depurada de cor rosa. Vemiz negro, brilhante, espesso e aderente.

Mértola, 85, GB, 700. Não ilustrado

Fragmento de asa horizontal pertencente a uma kylix. Espessura: $11 \mathrm{~mm}$. Pasta dura, compacta, bem depurada, de cor beije. Vemiz negro, brilhante, espesso e aderente.

Mértola, 87, 3E, la. Não ilustrado

Fragmento de asa horizontal pertencente a uma kylix. Espessura: $9 \mathrm{~mm}$. Pasta dura, compacta, bem depurada, de cor rosa esbranquiçada. Vemiz negro, brilhante, pouco espesso e muito pouco aderente.

Mértola, 84. Não ilustrado

Fragmento de asa horizontal pertencente a uma kylix. Espessura: $6 \mathrm{~mm}$. Pasta dura, compacta, bem depurada, de cor rosa. Vemiz negro acastanhado, baço, pouco espesso e muito pouco aderente.

\subsubsection{Páteras das formas 21 e 22}

As páteras das formas 21 e 22 de Lamboglia (as incurving rim bowl e outtumed rim bowl, respectivamente, da escola anglo-saxónica) aparecem geralmente associadas nos sítios da Península Ibérica. Este facto, que Lamboglia já referia em 1952, está actualmente confirmado, por exemplo no naufrágio del Sec (Arribas et al 1987). Os pés e as decorações destas páteras são, aliás, formal e tecnicamente muito semelhantes.

Os vasos da forma 21 (incurving rim bowl), cuja produção deve ter-se iniciado em Atenas no final do século V a.c. (Sparkes e Talcott, 1970: 131-132), têm o seu apogeu no século IV a.c., atingindo então a sua popularidade máxima \{ibid.). Perduram até à época helenística \{ibid.).

São vasos largos, de bordo muito reentrante, com pé arqueado e alto. Por vezes, este pé apresenta, na superfície de apoio, uma unha reservada.

Conimbriga, 37 (1998), 121-149 
As páteras forma 22 (<outturned rim bowl), tal como Lamboglia as definiu (1952), surgem em Atenas apenas na primeira metade do século IV a.c. (Sparkes e Talcott, 1970: 128-130). No entanto, as escavações da ágora de Atenas permitiram verificar que estas páteras foram precedidas por outras, do século $\mathrm{V}$ a.c. (forma 22 arcaica), que teriam dado origem às mais tardias (ibid.).

São vasos de bordo largo, com lábio exvertido formando um rebordo saliente. Os pés da forma 22 são altos e arqueados, sendo em tudo semelhantes aos da forma 21.

Em Mértola recuperou-se um bordo da forma 22 (Fig. 6, n. ${ }^{\circ}$ ) e seis fundos com pé, que podem corresponder à forma 21 ou à forma 22 , indistintamente. Dois dos pés possuem, na sua superfície de apoio, a característica unha destas formas (Fig. 6, n. ${ }^{\circ} 2$ e 3) e dois fundos internos apresentam decoração estampilhada (Fig. 6, n. ${ }^{\circ} 1$ e 4). Trata-se de palmetas impressas. Num dos fundos é visível uma palmeta de contornos bem definidos (Fig. 6 n. ${ }^{\circ} 4$ ), que corresponde a uma das quatro palmetas com folhas algo caídas, com volutas e núcleo central que, geralmente, se agrupam no centro do fundo das páteras das formas 21 e 22, decoradas. Podemos enquadrá-la no «taller» 5 do naufrágio de El Sec, onde tem, aliás, bons paralelos, justamente em palmetas impressas sobre fundos internos de formas 22 (Arribas et al., 1987, p. 269, Fig. 27, n. ${ }^{\circ} 62$ e 63).

O que resta da outra palmeta impressa, apenas uma pétala (Fig. 6, n. 1), não é suficiente para a enquadrarmos em nenhum dos «talleres» definidos no famoso naufrágio das Baleares.

Apresentamos aqui um outro fragmento de bordo (Fig. 7, n. ${ }^{\circ}$ 2) que pode pertencer tanto a uma Forma 21, como a uma Forma 21/25B. A pequena dimensão do bordo não permite estabelecer, com precisão, o seu diâmetro, o que dificulta uma precisa identificação formal.

Descrição dos fragmentos:

Mértola 79, GA, Que A, Z 2-3, n. ${ }^{\circ}$ 2. Fig. 6, n. ${ }^{\circ} 1$

Fragmento de pé e arranque de fundo de uma pátera da forma 21 ou 22. Pé alto, ligeiramente encurvado. No fundo interno, vestígios de uma estampilha. Áreas em reserva: ligação do pé à parede extema e superfície de apoio do pé. Diâmetro da base: $78 \mathrm{~mm}$. Espessura do pé: $7 \mathrm{~mm}$. Espessura do fundo: $5 \mathrm{~mm}$. Pasta dura, esponjosa, bem depurada, de cor esbranquiçada. Verniz acastanhado, brilhante, pouco aderente, pouco espesso.

Mértola, 85, 4F, la. Fig. 6, n. ${ }^{\circ} 2$

Fragmento de pé de uma pátera da forma 21 ou 22. Pé alto, ligeiramente encurvado, com ranhura (unha) na superfície de apoio, que se apresenta 
reservada. Diámetro da base: $121 \mathrm{~mm}$. Espessura do pé: $8 \mathrm{~mm}$. Espessura do fundo: $5 \mathrm{~mm}$. Pasta dura, compacta, bem depurada, de cor vermelha acinzentada. Vemiz negro, acetinado, pouco espesso, pouco aderente e com algum brilho.

Mértola, 95, Casa do Pardal. Fig. 6, n. ${ }^{\circ} 3$

Fragmento de pé de uma pátera da forma 21 ou 22. Ranhura (unha) na superfície de apoio, que se apresenta reservada. Diâmetro da base: $114 \mathrm{~mm}$. Espessura do pé: $13 \mathrm{~mm}$. Pasta dura, compacta, bem depurada, sendo visíveis minúsculas partículas de mica, de cor rosa clara. Vemiz negro, brilhante, acetinado, pouco espesso, pouco aderente.

Mértola, 95, Casa do Pardal. Fig. 6, n. ${ }^{\circ} 4$

Fragmento de fundo e arranque de pé de uma pátera da forma 21 ou 22. Ligação do pé à parede extema feita através de uma canelura reservada. No fundo interno, uma palmeta estampilhada de contornos bem definidos que corresponde a uma das quatro palmetas com folhas algo caídas, com volutas e núcleo central que, geralmente, se agrupam no centro do fundo das páteras das formas 21 e 22, decoradas. Podemos enquadrá-la no «taller» 5 de El See (Arribas et al., 1987). Diâmetro da base: $70 \mathrm{~mm}$. Espessura do fundo: $6 \mathrm{~mm}$. Pasta dura, compacta, bem depurada, de cor amarela clara. Vemiz negro, brilhante, acetinado espesso e aderente.

Mértola, 82, 6A, 61. Fig. 6, n. ${ }^{\circ} 5$

Fragmento de bordo e parede de uma pátera da forma 22. Lábio exvertido, formando um rebordo saliente de secção triangular. Diâmetro do bordo: 252 $\mathrm{mm}$. Espessura da parede: $5 \mathrm{~mm}$. Pasta dura, compacta, bem depurada, de cor rosa amarelada. Vemiz negro acastanhado, brilhante, aderente, pouco espesso.

Mértola, 79, A F, la. Fig. 7, n. ${ }^{\circ} 2$

Fragmento de bordo de uma pátera da forma 21 ou 21/25B. Bordo espessado e reentrante. Espessura da parede: $6 \mathrm{~mm}$. Pasta dura, compacta, mais ou menos depurada, de cor beije clara. Vemiz negro, pouco aderente e com algum brilho.

Mértola, 85, 4F, la. Não ilustrado

Fragmento de fundo e arranque do pé de uma pátera da forma 21 ou 22. $\mathrm{Na}$ superfície extema do pé são visíveis duas caneluras e na superfície interna apenas uma. O fundo extemo é reservado, mas era decorado por um círculo concêntrico de vemiz negro. Espessura do pé: $9 \mathrm{~mm}$. Espessura do fundo: 7 $\mathrm{mm}$. Pasta branda, compacta, bem depurada, de cor rosa. Vemiz negro, baço, pouco espesso e muito pouco aderente.

Mértola, 95, Casa do Pardal. Não ilustrado

Fragmento de pé de uma pátera da forma 21 ou 22. Pé anelar sem caneluras. Espessura do pé: $8 / 11 \mathrm{~mm}$. Pasta branda, compacta, bem depurada, de cor rosa. Vemiz negro, baço, pouco espesso e muito pouco aderente. 


\subsubsection{A forma $21 / 25 B$}

Lamboglia incluiu as pequenas taças, de pé largo em plano inclinado, na sua tipologia (1951) tendo-lhes atribuído a designação 21/ 25B. Estas taças têm uma origem ática e o seu fabrico iniciou-se em 425/400 a.c. Perduraram até ao período helenístico. Destinavam-se a servir, na mesa, sal ou outros condimentos.

$\mathrm{Na}$ ágora de Atenas esta forma foi designada por small bowl broad base.

Esta forma não é frequente na Península Ibérica, estando aparentemente circunscrita ao Levante e SE espanhol. Está presente na Catalunha, em Valência e na região de Múrcia.

No naufrágio de El See (Arribas et ai, 1987) recolheram-se 60 taças desta forma, muitas delas com os fundos internos decorados com 4 palmetas compactas e agrupadas em disposição radial (ibid.: 314314).

A forma 21/25B está totalmente ausente dos inventários portugueses, sendo, portanto, Mértola o primeiro sítio do nosso território onde foi recolhida, estando aqui representada por um único exemplar.

O fragmento recolhido em Mértola deve datar-se dos inícios do século IV a.c., ou mesmo dos finais do $\mathrm{V}$ a.c. A sua superfície interna é revestida de verniz negro, o que a distancia das produções do último quartel do século $\mathrm{V}$ a.c. No entanto, a ligação da parede ao corpo é ainda reservada, característica que o aproxima das produções mais antigas desta forma.

À semelhança dos exemplares de El See, o fragmento de Mértola foi, certamente, decorado, no fundo interno, com quatro palmetas compactas e agrupadas em disposição radial, das quais são apenas visíveis algumas pétalas de duas delas.

Descrição do fragmento:

Mértola, 95, muros interiores. Fig. 7 , n. ${ }^{\circ} 1$

Fragmento de fundo e pé de taça com pé largo. Áreas reservadas: superfície de apoio do pé e ligação do fundo à parede na superfície extema. Diâmetro do fundo: $56 \mathrm{~mm}$. Espessura do fundo: $4 / 12 \mathrm{~mm}$. Espessura da parede: $4 \mathrm{~mm}$. Pasta dura, compacta, bem depurada, cor laranja rosada. Verniz negro aderente e baço.

Decoração: pétalas de duas palmetas impressas no fundo interno. 


\subsubsection{O prato de peixe}

As páteras da forma 23 de Lamboglia são designadas na bibliografia arqueológica da especialidade por pratos de peixe. É provável que esta designação tenha origem nos peixes e cefalópodes pintados como figuras vermelhas em vasos desta forma (Sparkes e Talcott, 1970: 174). Mas também não é impossível que este nome derive do facto de estes pratos se destinarem a servir peixe ou seus derivados (Lamboglia, 1954:122). Aliás, como já referiu Morei (1981: 82), as duas hipóteses não são inconciliáveis.

Esta forma, que se caracteriza por possuir uma depressão central, no fundo, e um lábio pendente ou engrossado, encontra-se tanto decorada com figuras vermelhas como apenas coberta de verniz negro. Teve grande divulgação no Mediterrâneo Ocidental, onde aliás foi também produzida.

A produção de pratos de peixe da forma 23 encontra-se documentada em Kouass, Marrocos (Ponsich, 1969) e em Ibiza (Amo de la Hera, 1971).

Nos séculos III e II a.c., a forma está ainda em uso, sendo então fabricada no atelier das pequenas estampilhas, no atelier das páteras das três palmetas radiais e em campaniense A.

O fabrico dos pratos de peixe de verniz negro parece ter-se iniciado em Atenas um pouco antes de 400 (Sparkes e Talcott, 1970: 147-148 , Fig. 10).

São muito abundantes em sítios peninsulares, aparecendo nomeadamente em Huelva (Olmos Romera, 1977a), em Cádiz e em La Bastida (Lamboglia, 1954). Em Portugal encontram-se em Castro Marim (Arruda, 1997) e na necrópole do Senhor dos Mártires em Alcácer do Sal (Rouillard et al, 1988-89). No primeiro dos sítios, os pratos de peixe são também de verniz negro, mas em Alcácer do Sal esta forma está presente apenas na sua versão pintada com figuras vermelhas.

Em Mértola foi recolhido um fragmento de bordo de prato de peixe de fabrico ático (forma 23 de Lamboglia). Possui lábio apenas engrossado, que apresenta um pequeno ressalto na sua face interna. $\dot{E}$ muito semelhante aos de Castro Marim (Arruda, 1997), onde tem os seus melhores paralelos.

Descrição do fragmento:

Mértola 95, Casa do Pardal. Fig. 8, n. ${ }^{\circ} 7$

Fragmento de bordo e parede de um prato de peixe da forma 23 de Lamboglia. Bordo de aba curta. Canelura na parede interna imediatamente a 
seguir ao bordo. Diámetro do bordo: $254 \mathrm{~mm}$. Espessura da parede: $7 \mathrm{~mm}$. Pasta dura, compacta, bem depurada de cor laranja clara. Vemiz negro, muito brilhante e acetinado, pouco aderente e espesso.

\subsubsection{O skyphos}

O skyphos ático, o vaso para beber mais popular em Atenas durante os séculos VI a IV a.c., tem, no entanto, a sua origem numa outra cidade grega - Corinto. É de facto nas formas dos skyphoi corintios que os oleiros áticos se inspiraram para, em meados do século VI a.c., iniciarem a sua própria produção.

Inicialmente, os skyphoi áticos formavam uma única curva do fundo ao pé (Sparkes e Talcott, 1970: 84-85, Fig. 4). A partir dos finais do século V a.c., o bordo vai progressivamente exvasar-se, obrigando a parede do vaso a desenhar uma dupla curva $\{$ ibid.).

Inicialmente, as superfícies externas dos fundos dos skyphoi áticos eram totalmente cobertas de vemiz negro, apresentando-se em reserva apenas a superfície de apoio do pé. No entanto, esta prática cedo foi abandonada, tendo o típico skyphos ático a superfície extema do fundo completamente reservada com círculos de vemiz concêntricos \{ibid.).

A forma é bastante comum na Península Ibérica, fazendo parte dos inventários de muitos sítios arqueológicos (Trías, 1967).

Os skyphoi incluem-se na forma 43 de Lamboglia.

De Mértola é proveniente um fragmento de fundo e pé que pode incluir-se neste forma. A superfície extema do pé é reservada, o que indica que se trata de um vaso tardio, sendo o início do século IV a.c. a data provável da sua chegada ao Ocidente.

Descrição do fragmento:

Mértola, 84, 6A, 3. Fig. 8, n. ${ }^{\circ} 5$

Fragmento de parede, fundo e pé de skyphos ático. Pé arredondado. Áreas reservadas: fundo extemo e superfície de apoio do pé. Diâmetro da base: 60 $\mathrm{mm}$. Espessura da parede: $6 \mathrm{~mm}$. Espessura do fundo: $4 \mathrm{~mm}$. Pasta dura, compacta, bem depurada, de cor rosa clara. Vemiz negro, brilhante e pouco aderente.

\subsubsection{A lekythos arybalistica}

A lekythos é um vaso essencialmente destinado a conter azeite. O termo é geralmente aplicado a um vaso alto, com gargalo desenvolvido 
e corpo cilindroide assente sobre um pé anelar. Possui uma única asa, que é vertical.

Concebido como vaso funerário, é sabido que foi largamente utilizado em ambiente doméstico.

A designação de lekythos arybalistica é aplicada a um vaso cujo corpo, esferoidal, se aproxima do de um aryballos. $\mathrm{O}$ gargalo é mais curto que os das restantes lekythos e o pé é anelar.

A lekythos arybalistica foi chamada squat lekythos na ágora de Atenas, onde foi produzida a partir de 450 a. C. (Sparkes e Talcot, 1970: 153-155).

A pequena dimensão do fragmento recolhido em Mértola dificulta a sua integração nas quatro categorias definidas para a squat lekythos da ágora de Atenas (black and plain, patterned, vertical ribs e small and late). A atribuição de uma cronologia precisa toma-se, assim, mais difícil. No entanto, as dimensões que a lekythos de Mértola apresenta, nomeadamente o diâmetro na ligação do corpo ao colo e a espessura da parede, podem permitir, com algumas reservas, a sua integração no grupo «small and late» das squatslekythoi, cujos primeiros exemplares se datam de 430 a.c. A produção desta forma prolongou-se até ao século IV a.c., sendo então que atinge a sua maior popularidade.

Em Portugal, era conhecido apenas um único exemplar de lekythos arybalistica. Tinha sido identificado no Cabeço de Vaiamonte - Monforte (Amida, 1997). É, pois, uma forma rara no território actualmente português, à semelhança do que se sucede na Andaluzia ocidental, onde apenas se registou em Huelva, com um único exemplar (Olmos Romera, 1977)

Squat lektythoi semelhantes à de Mértola foram recolhidas no naufrágio de El See (Arribas et al., 1987: 371-377), contexto datado da primeira metade do século IV a.c.

Descrição do fragmento:

Mértola, 85, GB, 700. Fig. 8, n. ${ }^{\circ} 6$

Fragmento de bojo e arranque do colo de lekythos arybalistica. Ligação da pança ao colo feita através de ressalto. Espessura da parede: $3 \mathrm{~mm}$. Pasta dura, compacta, bem depurada de cor rosa acinzentada. Verniz negro com manchas alaranjadas, aderente e com algum brilho.

\subsubsection{As lucernas}

Em Mértola, recolheram-se três fragmentos de lucerna (dois ilustrados). Trata-se de dois bordos, com arranque dos respectivos bicos 
(Fig. 8, n. $08 \quad 3$ e 4 ) e um fragmento de parede (não ilustrado). Não possuímos, portanto a totalidade dos elementos que podem facilitar a classificação tipológica e a atribuição da cronologia, nomeadamente o fundo, o corpo e a asa.

No entanto, podemos verificar que o fragmento da Fig. 8, n. ${ }^{\circ}$, pertence a uma lucerna de paredes altas, separadas do bordo por uma canelura profunda, com um bico largo e estreito, características que correspondem às lucernas do tipo 25 (A ou $\mathrm{B})$ da ágora de Atenas (Howland, 1958) e VH de Corinto (Broneer, 1930). Esta forma está datada de meados do século IV a.c.

O exemplar da Fig. 8, n. $^{\circ} 3$ é mais difícil de classificar tipologicamente. Trata-se de uma lucerna de paredes altas, de bordo plano, pouco espesso e inclinado para o interior e com duas molduras no disco. Pode pertencer a uma forma 23 A da ágora de Atenas, VI de Corinto (¡ibid.), em uso desde o terceiro quartel do século $\mathrm{V}$ a.c. até ao primeiro quartel do século IV a.c. Esta classificação é, no entanto, aqui apresentada com muitas reservas.

As lucernas gregas são pouco frequentes nos contextos peninsulares. Estão, no entanto, presentes no naufrágio de El See (Arribas et al., 1987: 377-385), sendo abundantes em Ibiza, onde correspondem a cerca de 60\% das importações áticas (Sánchez Fernández, 1981).

Em Portugal conhece-se apenas um fragmento de lucerna, proveniente do castelo de Castro Marim (Arruda, 1997), datado da primeira metade do século IV a.c.

Descrição dos fragmentos:

Mértola, 95, Casa do Pardal. Fig. 8, n. ${ }^{\circ} 3$

Fragmento de bordo, parede e bico de lucerna. No disco, duas molduras definidas por três caneluras. Verniz interno e extemo. Diâmetro do bordo: 68 $\mathrm{mm}$. Espessura da parede: $4 \mathrm{~mm}$. Pasta dura, compacta, bem depurada de cor cinzenta. Verniz negro, brilhante, acetinado e pouco aderente.

Mértola, 95, Casa do Pardal. Fig. 8, n. ${ }^{\circ} 4$

Fragmento de bordo, parede e bico de lucerna, com canelura a separar o bico do funil. Verniz interno e extemo. Diâmetro do bordo: $40 \mathrm{~mm}$. Espessura da parede: $8 \mathrm{~mm}$. Pasta pouco compacta, bem depurada, com pequeníssimas partículas de mica de cor rosa alaranjada. Verniz negro, pouco aderente, baço e mal conservado.

Mértola, 95, Casa do Pardal. Não ilustrado.

Fragmento de parede e início do fundo de uma lucerna, com verniz em ambas as faces. Espessura da parede: 4/7 mm. Espessura do fundo: $7 \mathrm{~mm}$. Pasta 
dura, compacta, bem depurada, de cor rosa acinzentada. Vemiz negro, baço e pouco aderente

\subsubsection{As formas indeterminadas}

São cinco os fragmentos de cerámica ática que não permitiram um estudo tipológico (Fig. 9).

Em três casos, foram as reduzidas dimensões dos fragmentos que inviabilizaram qualquer tentativa classificatoria (Fig. 9, n.os 3,4 e 5). Para os fragmentos n. ${ }^{o s} 1$ e 2 da Fig. 9 não encontrámos quaisquer paralelos que permitissem uma identificação concreta.

No entanto, entendemos que merecem uma descrição pormenorizada, uma vez que alguns possuem decoração estampilhada que permite avançar dados sobre a cronologia das peças.

Descrição dos fragmentos:

Mértola, 86, 3N, lb. Fig. 9, n. ${ }^{\circ} 1$

Fragmento de vaso de cerâmica ática de forma não identificável (Askosl, Kernosl), com bordo e mamilo. Espessura: $7 / 14 \mathrm{~mm}$. Pasta dura, compacta, bem depurada de cor rosa acinzentada. Vemiz negro, brilhante, espesso e pouco aderente.

Mértola, 95, Casa do Pardal. Fig. 9, n. ${ }^{\circ} 2$

Fragmento de pé de cerâmica ática de forma não identificável. Parede extema do pé com duas caneluras e superfície de apoio em reserva. Diâmetro da base: $139 \mathrm{~mm}$. Espessura do pé: $5 \mathrm{~mm}$. Pasta compacta, bem depurada, sendo visíveis pequeníssimas partículas de mica e de cor rosa clara. Vemiz negro, acetinado, espesso aderente e baço.

Mértola, 87, LC, lb. Fig. 9 , n. ${ }^{\circ} 3$

Fragmento de parede, fundo e arranque de pé de vaso ático onde é visível uma decoração em guilloché, que certamente circundaria uma decoração estampilhada. Na superfície extema, a ligação do pé à parede é feita através de uma canelura em reserva. Espessura da parede: $5 \mathrm{~mm}$. Espessura do fundo: 3 $\mathrm{mm}$. Pasta dura, compacta, bem depurada de cor rosa clara. Vemiz negro, acetinado, espesso e pouco aderente.

Mértola, 95, Casa do Pardal, Corte III. Fig. 9 , n. $^{\circ} 4$

Fragmento de fundo de vaso ático. No interior uma palmeta estampilhada com folhas compridas, soltas e caídas, com volutas e núcleo central. Esta decoração aproxima-se dos «talleres» 2 e 5 de El Sec (Arribas, 1987: $207-$ -209). Espessura do fundo: $6 \mathrm{~mm}$. Pasta dura, compacta, bem depurada de cor rosa. Vemiz negro, acetinado, aderente, espesso e pouco brilhante. 
Mértola, 95, Casa do Pardal, Corte III. Fig. 9, n. ${ }^{\circ} 5$

Fragmento de fundo de vaso ático. No interior urna palmeta estampilhada com folhas curtas e soltas, com volutas e núcleo central. Tal como o fragmento anterior, esta decoração tem os seus melhores paralelos nos «taller» 2 e 5 de El Sec (ibid., 1987: 207-209). Espessura do fundo: $5 \mathrm{~mm}$. Pasta dura, compacta, bem depurada de cor rosa. Vemiz negro, acetinado, aderente, espesso e baço.

(A.M.A.eP.B.)

\subsection{Comentário final à cerâmica ática de Mértola}

À semelhança do que sucede nos outros sítios arqueológicos do Sul de Portugal e da Andaluzia Ocidental, a cerâmica ática de figuras vermelhas recolhida em Mértola é relativamente escassa, sobretudo se a compararmos com a de vemiz negro. Também as formas presentes não diferem do habitualmente conhecido no Sudoeste da Península Ibérica em sítios de habitat.

A grande maioria da cerâmica ática de figuras vermelhas de Mértola data da primeira metade do século IV a.c., ou seja da fase II do Período Clássico Tardio e pertence ao chamado estilo Kerch. Nesta época, as formas são exclusivamente kylikes, e, muito possivelmente, são, na totalidade, obra do gmpo do Pintor de Viena 116.0 que resta da decoração que estas taças apresentam é suficiente para supor que os motivos que as decoravam seriam jovens em himation. Já dissemos que estes são justamente os motivos mais frequentes nas taças pintadas pelo gmpo deste Pintor. Abundantíssimas na Andaluzia (Rouillard, 1975), parecem ser as únicas importações de taças de figuras vermelhas para o território actualmente português durante o século IV a.c. (Amida, 1997).

Um único fragmento de cerâmica ática de figuras vermelhas é datado do século $\mathrm{V}$ a.c., mais precisamente do seu último quartel. É também o único que não pertence a uma kylix. Trata-se de um krater, possivelmente pintado pelo pintor de Dinos ou Chrysis e pertence à fase I do Período Clássico Tardio. Como já anteriormente referimos, este Pintor não está bem representado na Península Ibérica, conhecendo-se apenas um outro vaso cuja autoria lhe pode ser atribuída, e que é também proveniente do actual território português, concretamente do povoado de Santa Olaia, na Figueira da Foz (Arruda, 1997).

O estudo tipológico e o respectivo enquadramento cronológico dos vasos áticos de vemiz negro encontrados em Mértola permitiu verificar

Conimbriga, 37 (1998), 121-149 
que, à semelhança do que se registou na cerâmica pintada com figuras vermelhas, as importações se iniciaram no último quartel do século $\mathrm{V}$ a.c. Estas importações perduram, porém, durante toda a primeira metade do século IV a.c. Deve, no entanto, referir-se que as importações do século V a.c. se resumem, quase exclusivamente, a taças (11 tipo Castulo e 1 stemless cup do tipo plain rim). Pelo contrário, os vasos do século IV a.c. são tipologicamente mais variados, apesar de as kylikes e as páteras das formas 21 e 22 dominarem no inventário.

Deve-se ainda, no entanto, realçar que, na globalidade das importações, as taças (Castulo ou plain rim) são largamente maioritárias, correspondendo a $34,4 \%$ dos vasos de verniz negro. Se a estes dados fossem ainda acrescentados os dos vasos de figuras vermelhas, esta percentagem cresceria até aos $43 \%$, o que é de facto muito significativo.

E, pois, também, claro que as formas aqui apresentadas não distanciam o conjunto de Mértola do que era já conhecido na Península Ibérica, apesar de duas peças serem ainda inéditas no território actualmente português, como é o caso da forma $21 / 25 \mathrm{~B}$ e da lekythos arybalistica.

Uma última observação diz respeito às formas e funções dos vasos inventariados.

A maioria das formas são abertas (taças, skyphoi e páteras) e destinam-se ao consumo de vinho e de alimentos. Relacionam-se, pois, directamente com o symposium.

Como um de nós (A.M.A.) disse já, noutro local, «o aparecimento destes recipientes em lugares de habitat pressupõe a sua utilização quotidiana e mostra que os vasos gregos, mesmo nas regiões mais periféricas e não helenizadas do Mediterrâneo, não eram apenas destinados a constituírem oferendas funerárias.(...). A utilização de determinadas formas na função de origem, muito específica, para que foram concebidas em Atenas (vasos de mesa), revela uma adopção por parte dos povos ibéricos de alguns hábitos, ou talvez mesmo modelos culturais Este mediterrâneos, muito concretamente gregos.» (Arruda, 1997).

(A.M.A.) 


\section{A cerámica ática de Mértola no contexto das exportações gregas para o SW peninsular}

A cerâmica ática de Mértola tem, necessariamente, que relacionarse com as restantes importações gregas do Ocidente peninsular, uma vez que o conjunto aqui estudado em nada se diferencia dos conhecidos nos outros povoados do SW.

$\mathrm{Na}$ verdade, o espólio cerâmico grego do século $\mathrm{V}$ e IV a.c. encontrado em Mértola é, como vimos, muito semelhante ao que se verifica na Andaluzia ocidental e no sul do território actualmente português.

Assim, resta-nos discutir, em termos estritamente regionais, o significado da existência deste conjunto, num sítio do Baixo Alentejo e de que forma e em que local se processou o abastecimento destas cerâmicas.

Relativamente à última questão, é fundamental ter presente que, como referimos no ponto 1, Mértola é o ponto extremo da navegabilidade do rio Guadiana. Mas não podemos também esquecer que na foz deste mesmo rio, e também na margem direita, se localiza o castelo de Castro Marim, sítio que importou cerâmica ática exactamente no mesmo momento que Mértola. Aliás, o catálogo das formas presentes nos dois sítios assemelha-se muitíssimo, isto independentemente de algumas presenças e ausências.

Por exemplo, a forma $21 / 25 \mathrm{~B}$ e a lekythos arybalistica presentes em Mértola não foram identificadas em Castro Marim, que forneceu, em contrapartida, uma pátera Jehasse 116, ausente do lote de Mértola (ibid.). As semelhanças entre os dois conjuntos são, no entanto, impressionantes. As kylikes (Castulo e plain rim cup), as páteras das formas 21 e 22, os skyphoi, os pratos de peixe e até mesmo as lucernas de ambos os sítios parecem ser provenientes das mesmas oficinas e quiçá compradas aos mesmos navios mercantes.

Desta forma, duas hipóteses são possíveis:

1. a cerâmica grega era comprada directamente em Mértola a comerciantes mediterrâneos que subiam o Guadiana, após terem abastecido destes mesmos produtos a população que habitava no Castelo de Castro Marim;

2. a cerâmica grega encontrada em Mértola era obtida em Castro Marim, de acordo com as relações comerciais inter-regionais que certamente se estabeleceram entre estes dois sítios que, durante a Idade do Ferro, adquirem grande importância.

Conimbriga, 37 (1998), 121-149 
Atendendo ao que conhecemos do comércio grego com outras regiões, mesmo peninsulares, a $2^{\text {a }}$ hipótese poderia parecer mais plausível. De facto, tem sido considerado ponto assente que as cerâmicas encontradas no interior não podem ser o resultado de contactos directos com populações mediterrâneas, tendo sido adquiridas no litoral onde os navios orientais aportavam.

Um outro factor poderia determinar a nossa preferência pela $2^{\text {a }}$ hipótese. Mesmo admitindo que o Sul de Portugal não se constituía, durante a Idade do Ferro, como uma única unidade política, existiam seguramente laços estreitos entre as várias entidades representadas neste relativamente vasto território. Esses laços estavam certamente consubstanciados em relações de tipo fundamentalmente comercial, entre o litoral e o interior, este rico em minério e aquele com um aproveitamento mais acentuado dos recursos marítimos, onde o comércio a longa distância representava certamente um papel relevante.

No entanto, é sabido que o Guadiana é facilmente navegável até Mértola e as marés fazem-se sentir até aqui com intensidade. Também não restam dúvidas que houve, neste local, um importante porto fluvial, que muito provavelmente estava em actividade durante a Idade do Ferro.

Somos assim obrigados a concluir que a investigação dos níveis da Idade do Ferro de Mértola é fundamental para podermos contextualizar devidamente o lote de cerâmicas gregas aqui estudado e para compreender o seu significado em termos de comércio inter-regional e a longa distância.

$\mathrm{O}$ que de qualquer forma fica muito claro é o facto de a população que, durante a $2^{\text {a }}$ metade do I milénio a.c., estava instalada em Mértola era detentora de um efectivo poder de compra e tinha adquirido hábitos sociais e alimentares, até ao momento, estranhos à região, utilizando quotidianamente vasos fabricados em Atenas.

No espaço urbano de Mértola, viveria, pois, uma elite, política e socialmente superior, que controlaria a extracção de minério e a produção agrícola do seu território imediato e que mantinha, ou directamente ou através do litoral, contactos com o mundo mediterrâneo.

(A.M.A.)

Conimbriga, 37 (1998), 121-149 


\section{BIBLIOGRAFÍA}

AMO DE LA HerA, Mariano del (1970) - La ceramica campaniense de importación y la imitaciones campanienses en Ibiza. Trabajos de Prehistoria. Madrid: CSIC, 27, p. 201-256.

ARribas, Antonio; Trías, M. Gloria; CerdÁ, Damián e HOZ, Javier (1987) - El Barco de El Sec (Calvià, Mallorca). Estudio de los materiales. Mallorca: Ajuntament de Calvià e Universität de les illes Balears.

ARrudA, A. M. (1994) - Panorama das importações áticas em Portugal. Huelva Arqueológica (Actas do Simposio: Iberos y Griegos: Lecturas desde la diversidad. Ampúrias, 1991). Huelva.: Diputación Provincial de Huelva, 13, 1, p. $129-154$.

ARrudA, A. M. (1997) - A cerámica ática do Castelo de Castro Marim. Lisboa: Colibri. Colecção «Arqueologia \& Historia Antiga».

BEAZLEY, John Davidson (1974) - Attic red-figure vase-painters. 2a ed., 3 vols. New York: Hacker Art Books.

FARIA, António M. (1994) - Uma inscrição em caracteres do Sudoeste achada em Mértola. Vipasca. Aljustrel, 3, p. 61-3.

LAMBOGLIA, Nino (1950). Per una clasificazione preliminare de la ceramica campanula. Bordighera: Istituto Intemazionale di Studi Liguri, p. 139-206.

LAMBOgLiA, Nino (1954) - La ceramica precampana della Bastida. Archivo de Prehistoria Levantina. Valencia: Diputación Provincial de Valencia, 5, p. 105-139.

Morel, Jean Paul (1981) - Céramique Campanienne: les Formes. Paris: École Française de Rome.

Oliveira, Tomás e Oliveira, Victor (19965) - Síntese da Geologia da faixa piritosa em Portugal e das principais minerações associadas. In Mineração do Baixo Alentejo. Castro Verde: Câmara Municipal de Castro Verde, p. 8-27.

Olmos RomerA, Ricardo (1977) - La cerámica atica del Cabezo de San Pedro. Huelva Aarqueológica. Huelva: Diputación Provincial de Huelva, 3, p. 377-393.

Pellicer Catalán, Manuel (1982) - Las cerámicas del mundo fenicio en el Bajo Guadalquivir: evolución y cronologia según el Cerro Macareno. In Phönizier im Western.. Madrider Beitrage. Madrid: Deutsches Archäologisches Institut. Madrid, 8, p. 371-403.

Ponsich, M. (1969) - Note préliminaire sur l'industrie de la céramique préromaine en Tingitane (Kouass, région d'Arcila). Karthago. Paris: Université de Paris - Sorbonne, Centre d'Études Archéologiques de la Méditerranée Occidentale, 15, p. 75-97.

REgO, Miguel; GuERrERO, Olga e GóMEZ, Francisco (1996) - Una ciudad mediterenea en el contexto de la Edad del Ierro del Bajo Guadiana. In Actas de las primeras jomadas transfonterizas sobre la contienda hispano-portuguesa (2 a 4 de Junio de 1995). Aroche: Escuela Taller ContiendaTomo, 1, p. 119-132.

Rouillard, Pierre; PAIXÃo, Antonio Cavaleiro; VIllanUeVA-PUIG, Marie Christine e DuRAND, Jean-Louis (1988-89) - Les vases grecs d'Alcácer du Sal (Portugal). O Arqueólogo Português. Lisboa: Museu Nacional de Arqueologia e Etnologia, série 4, voi. 6/7, p. 43-108. 
Presedo Velo, Francisco (1982) - La necrópolis de Baza. Excavaciones Arqueológicas en España. Madrid: Ministério de Cultura, Dirección General de Bellas Artes, Archivos y Bibliotecas, 119.

SANCHEZ FERnÁNDEZ, Carmen (1981) - La ceramica ática de Ibiza en el Museo Arqueológico Nacional. Trabajos de Prehistoria. Madrid: Consejo Superior de Investigaciones Científicas, 38, p. 218-316.

SPARKES, Brian, A. e TALCOTT, Lucy (1970) - Black and plain pottery of the 6th., 5th. and 4th. centuries B.C.. The Athenian Agora, Vol. XII. Princeton, New Jersey: American School of Classical Studies at Athens.

TORRES, Cláudio e MACIAS, Maciel (1994) - Mértola romana. In Atlas de Arqueologia. Lisboa: Edições Zairol, p. 366-367.

TRÍAS DE ARribas, M. Gloria (1967-68) - Cerámicas griegas de la Peninsula Iberica. Valência: The William L. Bryant Foundation. 2 volumes.

Conimbriga, 37 (1998), 121-149 


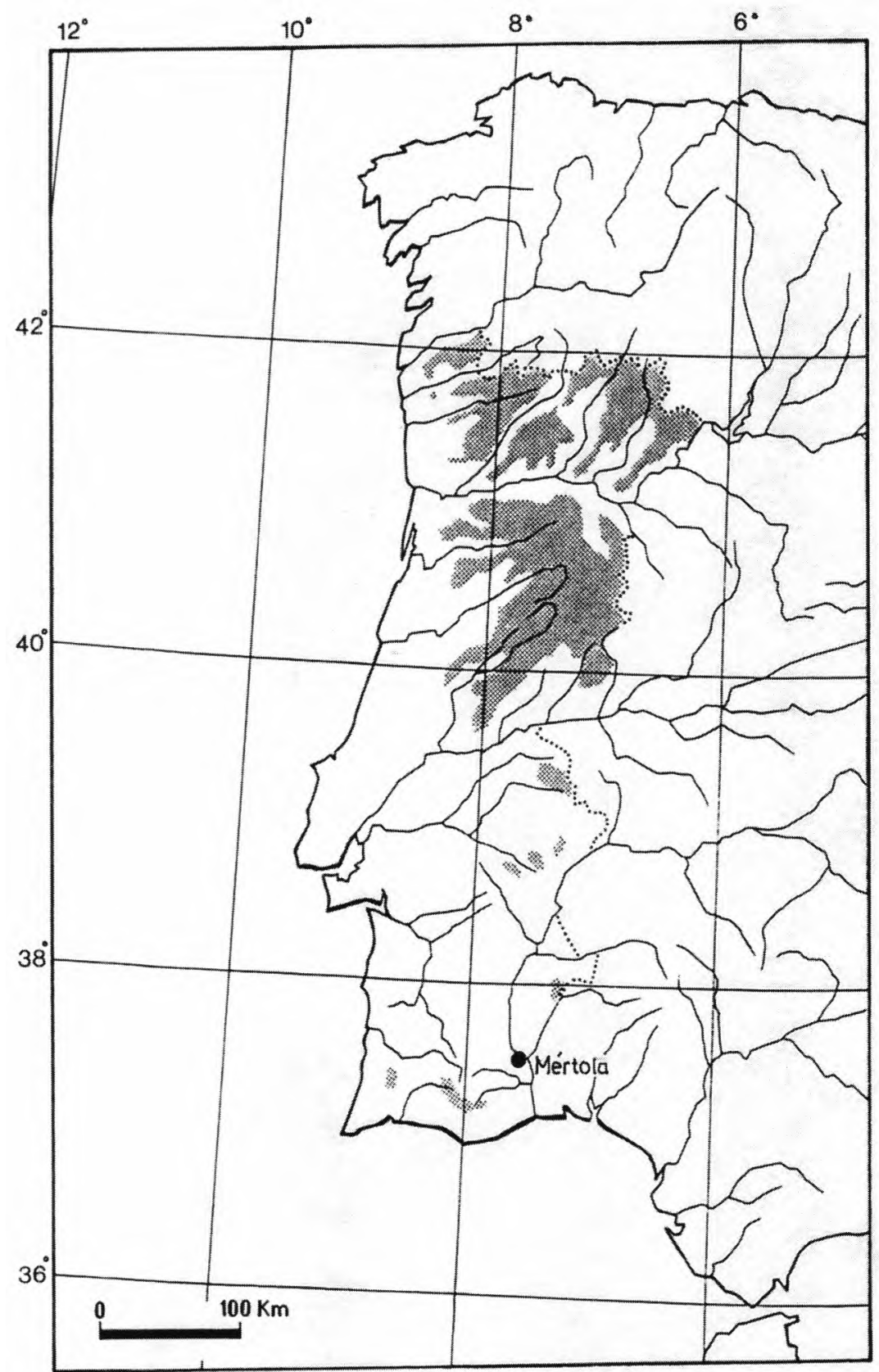




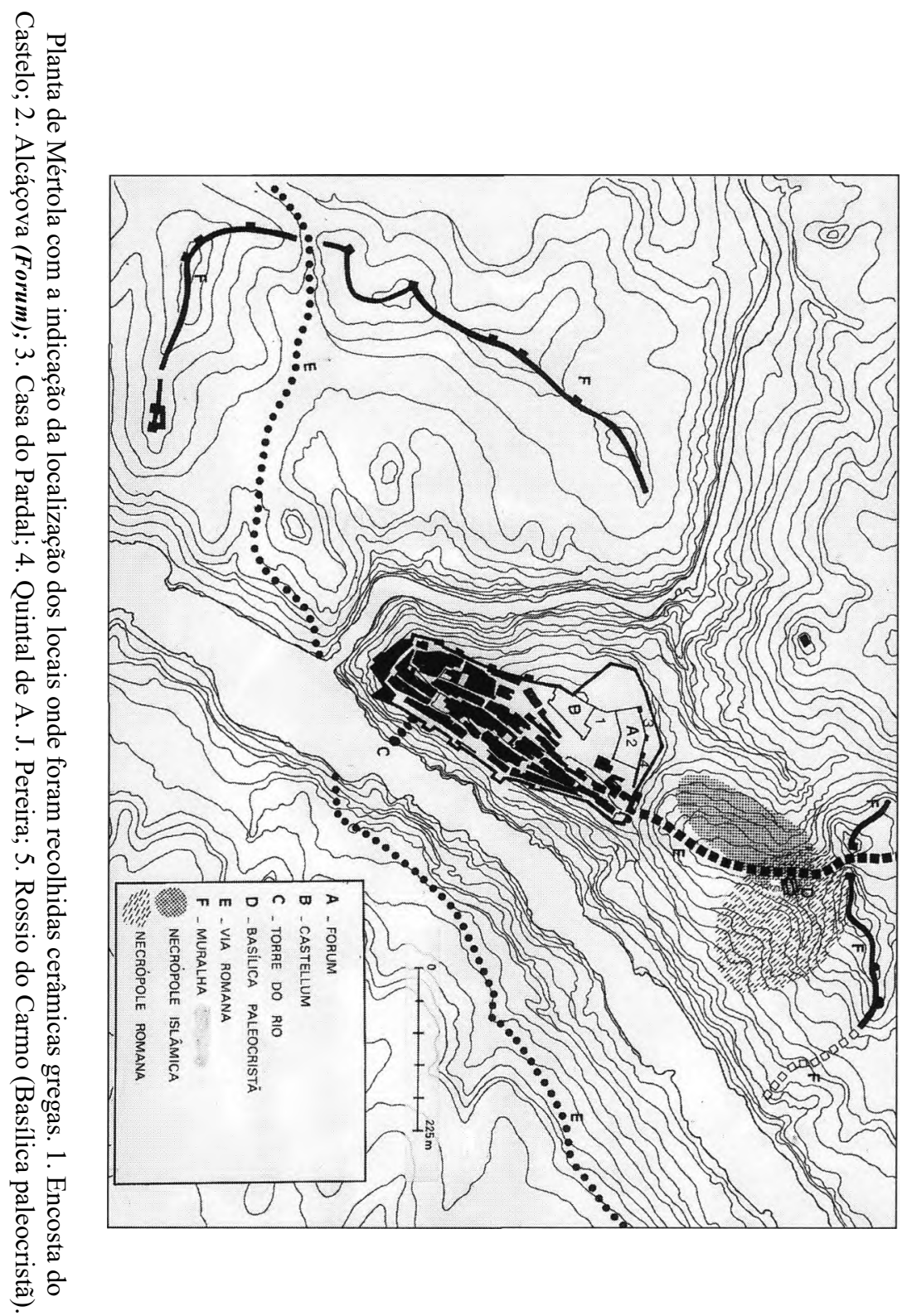


EsT. III

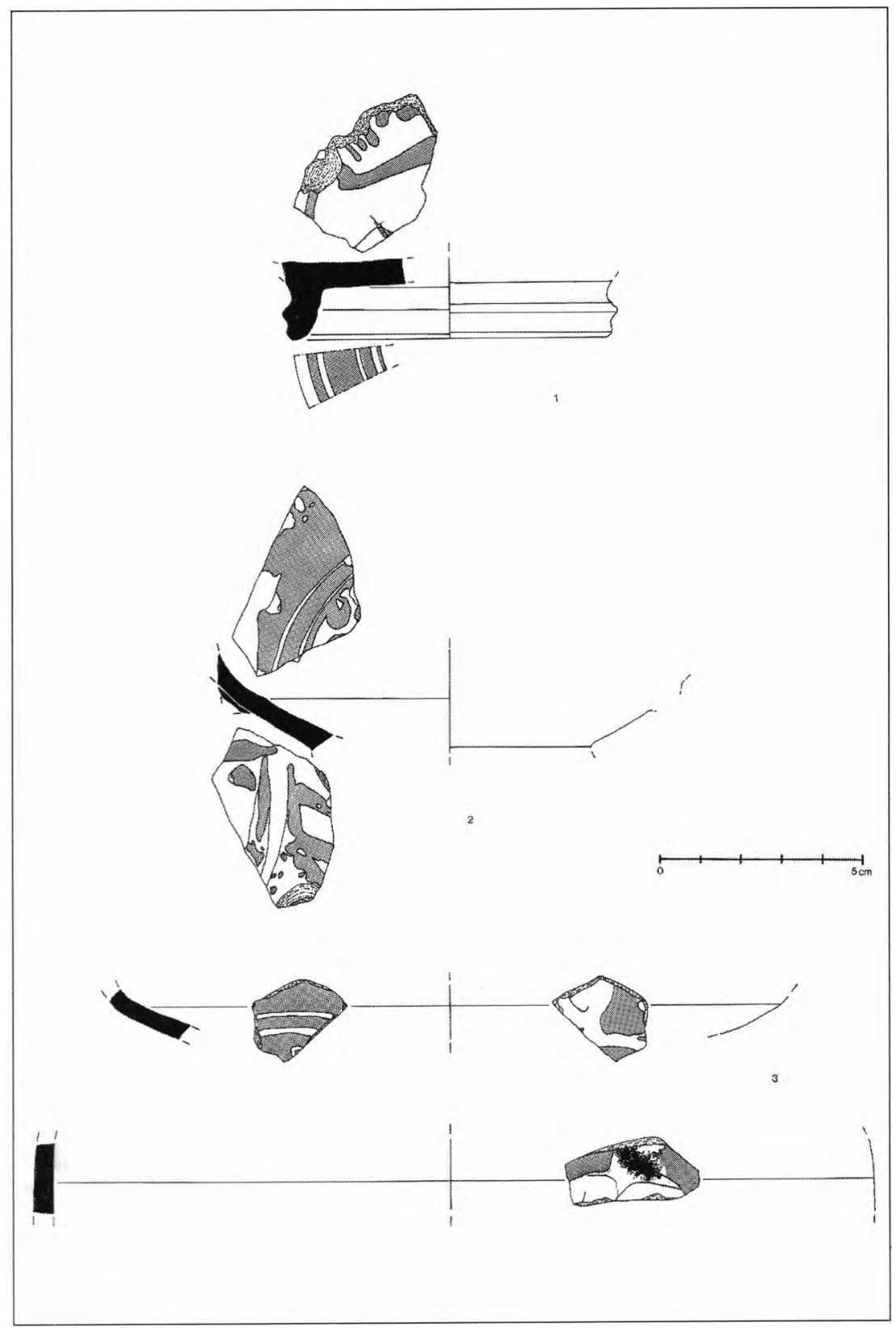

Cerâmica ática de figuras vermelhas. 
EST. IV

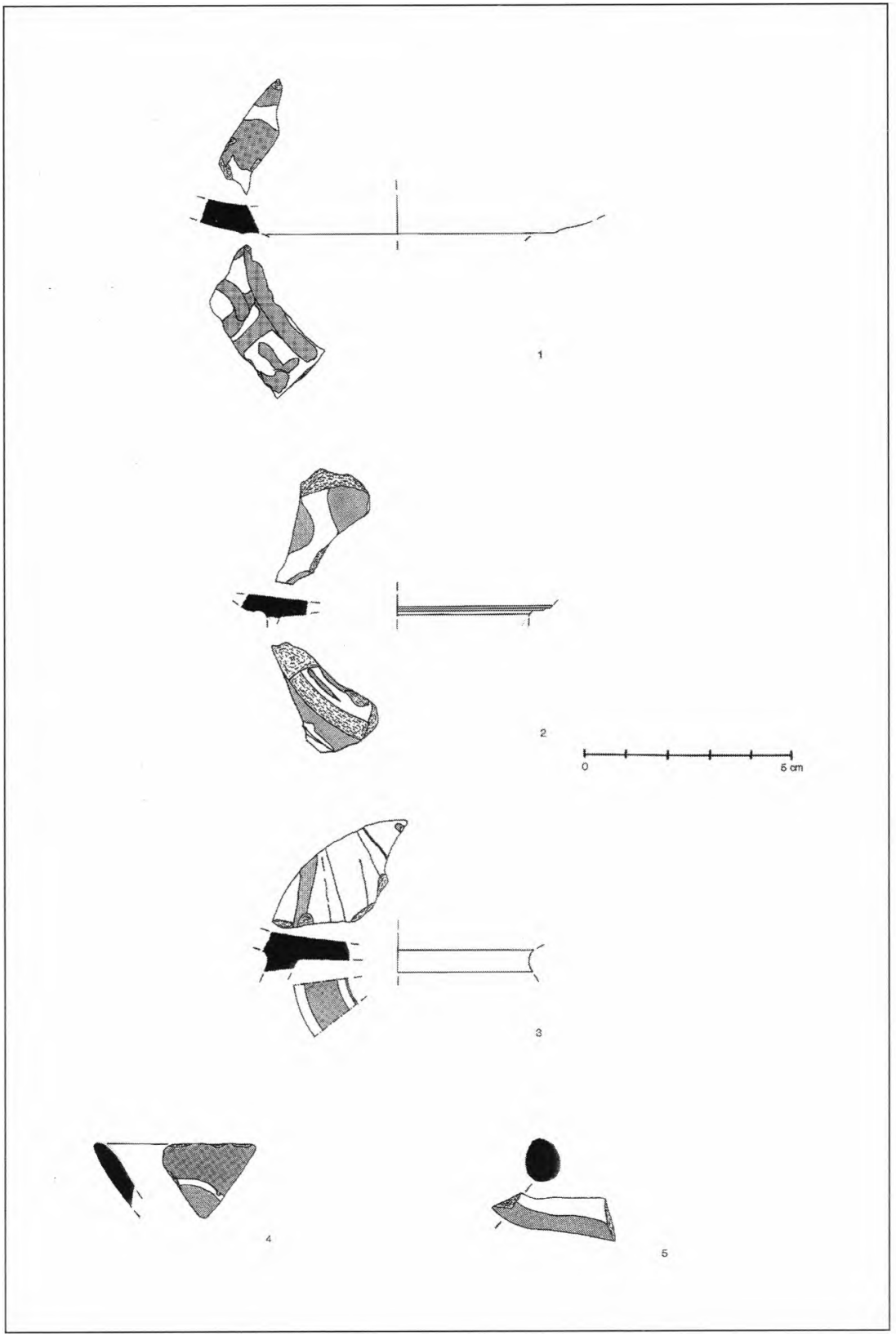

Cerâmica ática de figuras vermelhas. 


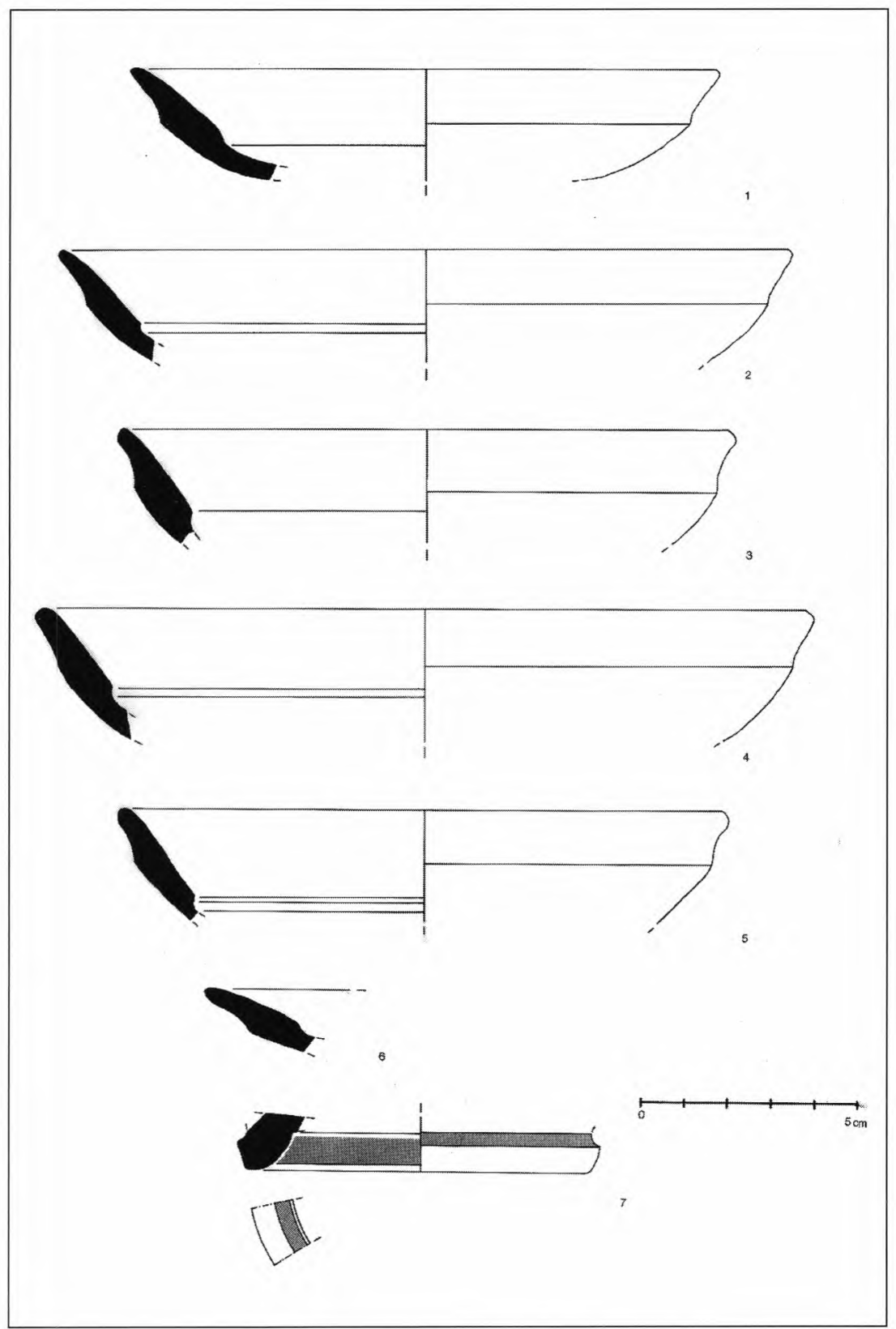

Cerâmica ática de verniz negro. Taças Castulo. 


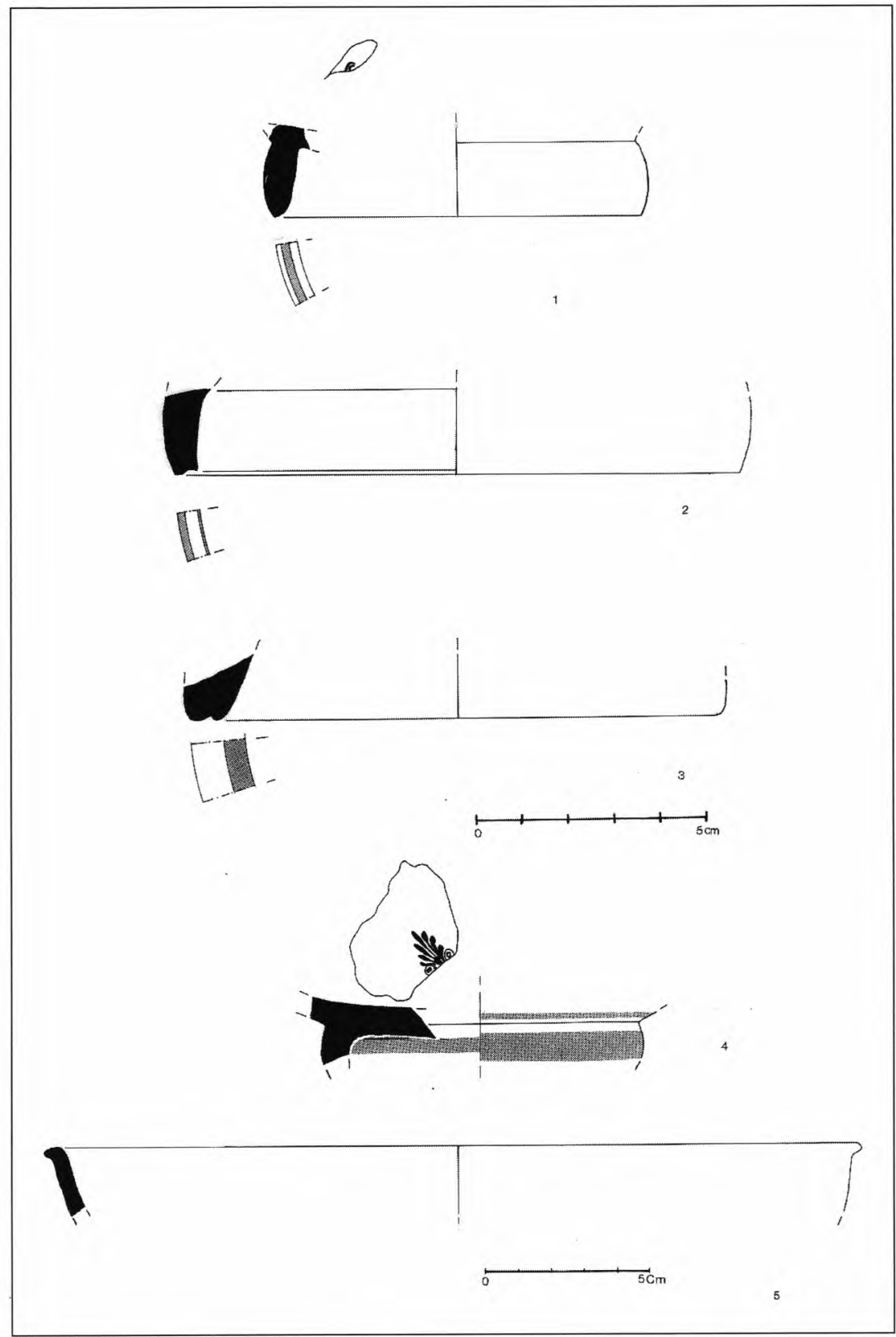

Cerâmica ática de verniz negro. Formas 21/22 
EsT. VII

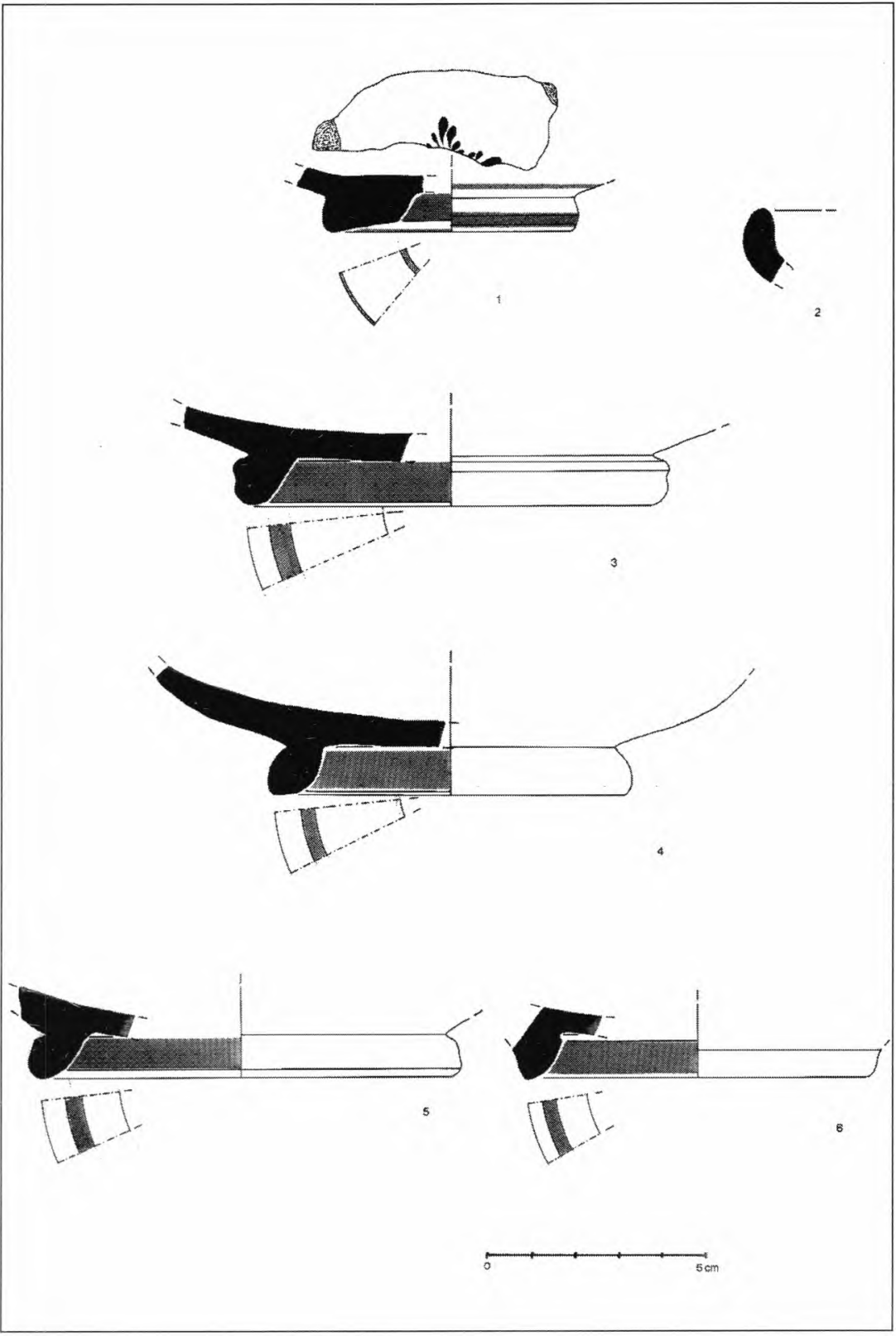

Cerâmica ática de verniz negro.

1. Forma 21/25B; 2. Forma 21 ou 21/25B; 3.-7. Stemless cups 


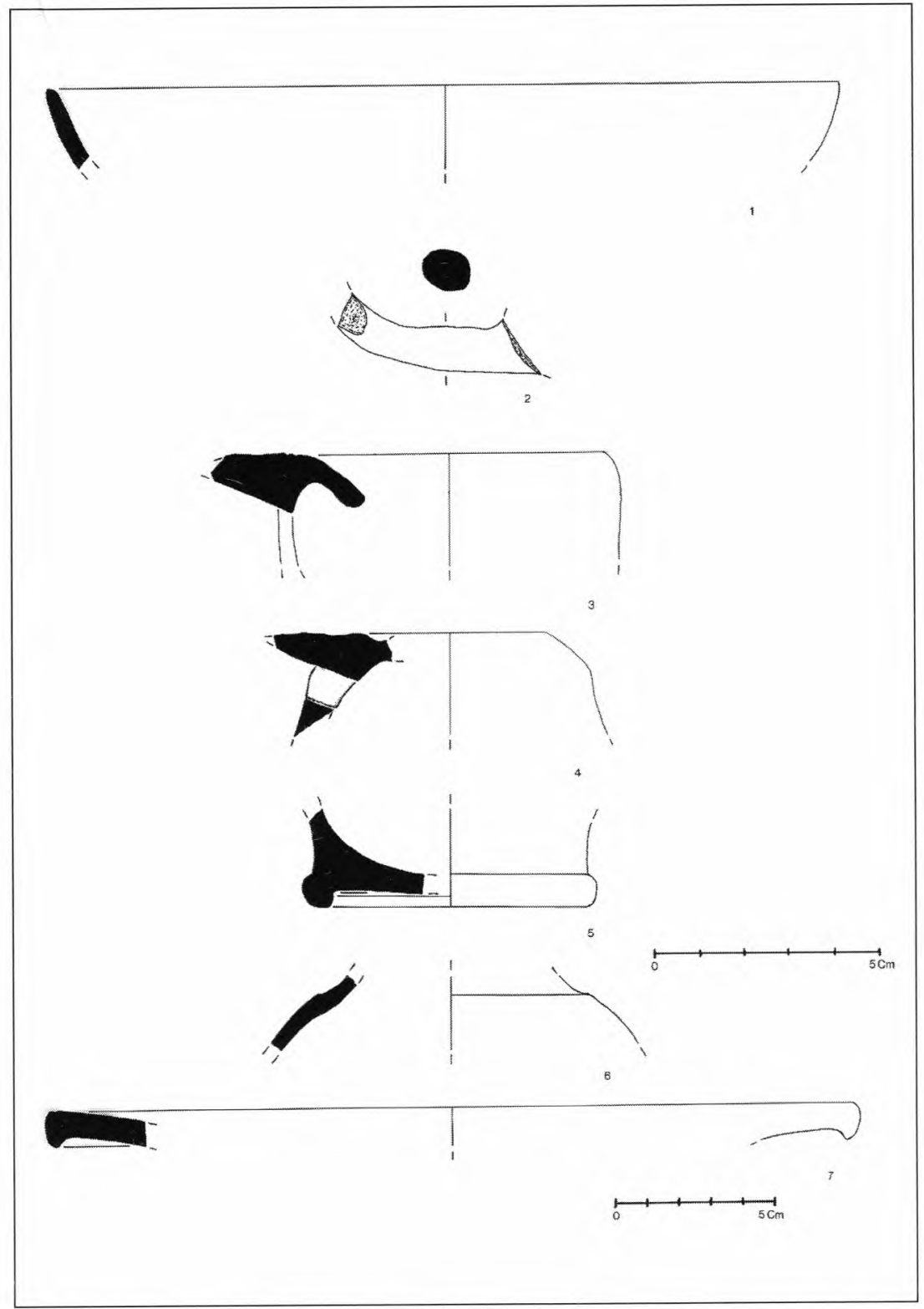

Cerâmica ática de verniz negro.

1. e 2. Stemless cups; 3. e 4. Lucernas; 5. skyphos

6. lekythos arybalistica; 7. Prato de peixe 
Est. IX

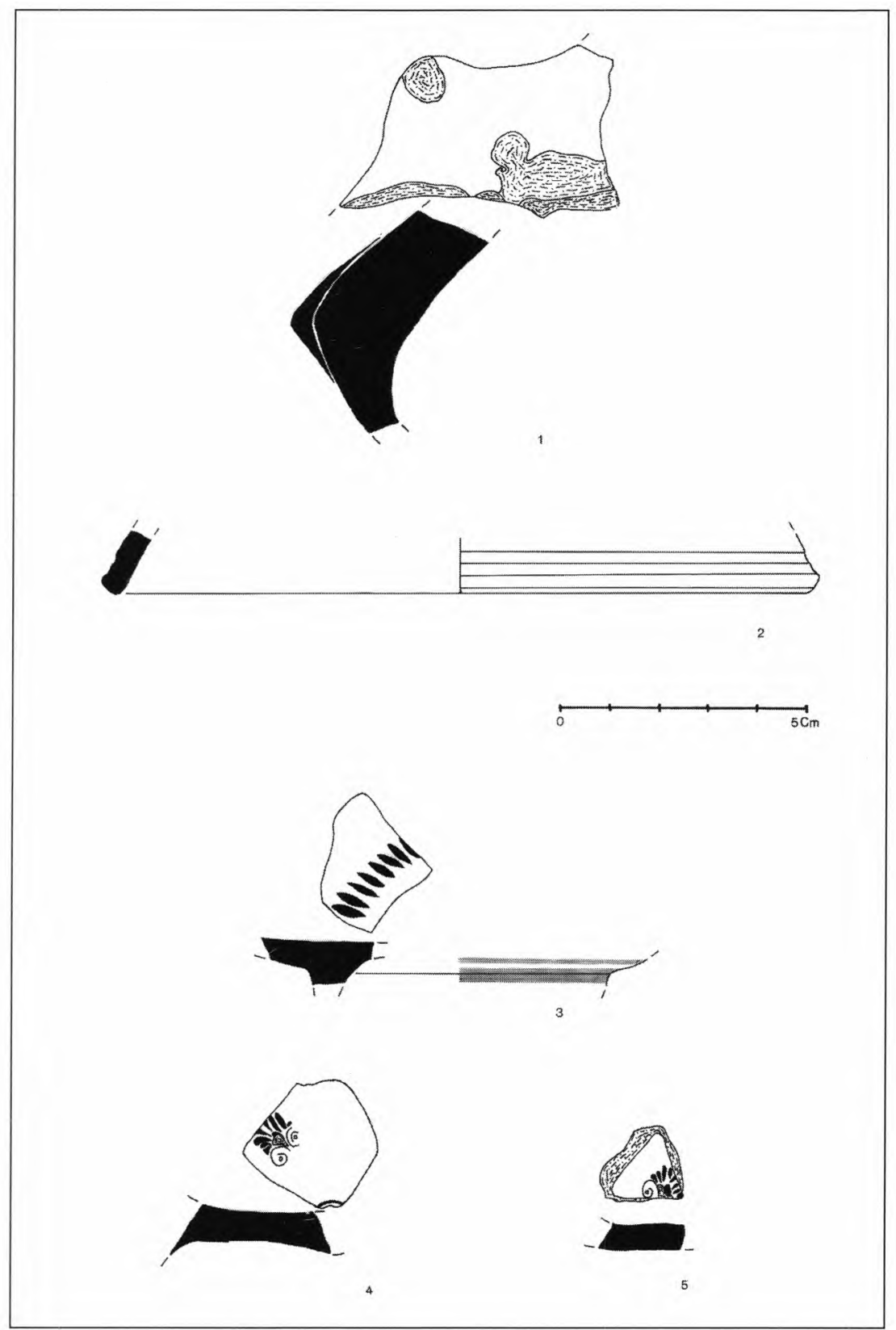

Cerâmica ática de verniz negro. Formas indeterminadas. 